\title{
A Proposal to Recognize Component Works: How a Teddy Bears on the Competing Ends of Copyright \\ Law
}

\author{
Christian H. Nadan $\uparrow$
}

We live in an age of technological revolution, where much technological progress builds upon prior innovation. Yet copyright law categorically denies protection to works that build on existing copyrighted works. This Comment proposes extending copyright protection to component worksthose that function only in conjunction with the preexisting work. The author argues that recognizing component works would further copyright law's two opposing goals: it would provide authors with incentives to create works and would improve the public's accessibility to knowledge and innovation. Since a component work does not replace the preexisting work but functions with it, one must purchase the preexisting work to use the component works doctrine can maximize the other goal of expanding the public's access to innovation.

\section{INTRODUCTION}

In the wake of the computer revolution, copyright is perhaps the most volatile area of law. Only a few years after Congress enacted the 1976 Copyright Act, ${ }^{1}$ which comprehensively overhauled copyright law, parts of the new Act were outdated. New technological developments have raised questions unthinkable in 1976. As commentators have observed, "As young as the 1976 Copyright Act is, and as prescient as its drafters may have been, the statute has nonetheless been overtaken-and its text put under stress-by the advent and growth of technologies."2 Since rewriting the 1976 Act to accommodate these developments could take years, if not decades, ${ }^{3}$ the courts are now without congressional gui-

$\dagger$ B.A. 1988, Stanford University; J.D. candidate 1991, Boalt Hall School of Law, University of California, Berkeley. I would especially like to thank Professor John G. Fleming for sharing his interest in copyright law, Tay Via and Gail Engstron for their editing, iny friends for helping out, and Michele Milnes for everything. This Cominent will be entered in the Nathan Burkan conpetition.

1. 1976 Copyright Act, 90 Stat. 2541 (codified at 17 U.S.C. $\$ \S 101-914$ (1988)).

2. A. Latman, R. Gorman \& J. Ginsburg, COPYRight For the Nineties at vii (3d ed. 1989).

3. Copyright law was previously overhauled in 1909. See Copyright Act, ch. 320, 35 Stat. 1075 (1909) (current version at 17 U.S.C. $\$ 101-914$ (1988)). The Act is particularly difficult to amend due to its very broad subject matter coverage. See, e.g., Cohen, Software Issue Kills Liberal 
dance to grapple with the emerging problems.

One new problem springs from the nature of modern technology and technological advances. Much technological progress builds upon existing technology. Moreover, technology is peculiarly susceptible to upgrades and improvements, rather than simple replacement. A computer program that can make a personal computer run a particular apphcation more quickly is one such improvement. Yet to the extent the two have program codes that are at all similar, courts may deem the later improvement a copyright infringement and prohibit its dissemination. ${ }^{4}$

This Comment proposes to solve this problem by recognizimg a new type of work, a "component work." A component work is a work that goes with another work; it does not replace it. Indeed, it improves it. ${ }^{6}$ Thus, the existence of the component work will eulrance the market for the original work. A computer chip that makes a particular personal

Amendment to Copyright Laws, N.Y. Times, Oct. 13, 1990, $§ 1$, at 1, col. 1 (Congress rejected a bill allowing authors to quote liberally from unpublished material because protection of computer software would be diminished).

4. See, e.g., Midway Mfg. Co. v. Strohon, 564 F. Supp. 741 (N.D. Ill. 1983).

5. The concept "component work" las not been recognized before. The 1909 Copyright Act referred to component works in the context of individual articles in "magazines, periodicals and the like," but the term there was used to mean merely "section" or "part." Markham v. A.E. Borden Co., 206 F.2d 199, 200-01 \& n.1 (1st Cir. 1953) (quoting 17 U.S.C. \& 3 (1909)). The term was rendered obsolete and was not employed in the 1976 Act. Brylawski, E.T.: An Extraterrestrial Caught in a Copyright Dilemma, 52 GEO. WASH. L. REv. 395, $396-97$ (1984).

One earlier commentator wrote of a concept somewhat like coinponent works, but referred to them as "dependent works." See Gemignani, Copyright Protection: Computer-Related Dependent Works, 15 RUTGERs COMPUTER \& TECH. L.J. 383, 383-87 (1989). To Gemignani, a dependent work is one based on a preexisting work. Gemignami's concept is overly broad and fails to exclude works that replace the original work. Deeming Gemignani's dependent works noninfringing would thus fail to protect authors' incentives. Moreover, Gemignani did not adequately address the derivative nature of dependent works. See id. at 385, 409-10; see also Note, Toward a Unified Theory of Copyright Infringement for an Advanced Technological Era, 96 HARv. L. REv. 450, 459 (1982) (noting that new technology applied to existing works may "benefit the copyright owner by generating additional demand for his work and ultimately increasing the work's dissemination").

Courts lave never explicitly recognized component works. Although cases lave arisen involving nonreplacing, enhancing works, the courts have decided these cases without enunciating a component works concept. These courts have apphied varied tests. See, e.g., Vault Corp. v. Quaid Software, Ltd., 847 F.2d 255, 267-68 (5th Cir. 1988) (finding no infrimgement using the "substantial similarity" test); Worlds of Wonder, Inc. v. Veritel Learning Sys., 658 F. Supp. 351, 355-56 (N.D. Tex. 1980) (finding infringement using the "look-and-feel" test); Worlds of Wonder, Inc. v. Vector Intercontinental, Inc., 653 F. Supp. 135, 139-40 (N.D. Ohio) (same), later proceeding 1 U.S.P.Q.2d (BNA) 1982 (N.D. Ohio 1986); Midway Mfg. Co. v. Artic Int'l, Inc., 547 F. Supp. 999, 1012-14 (N.D. III. 1982) (finding infringement using the "substantial similarity" test), aff'd, 704 F.2d 1009 (7th Cir.), cert. dcnied, 464 U.S. 823 (1983); New York Times Co. v. Roxbury Data Interface, Inc., 434 F. Supp. 217 (D.N.J. 1977) (finding no infringement using a "fair use" analysis).

One court, however, has employed a concept similar to component works. See Lotus Dev. Corp. v. Paperback Software Int'1, 740 F. Supp. 37, 78-79 (D. Mass. 1990) (using the term "add-in" to describe programs designed to be used in conjunction with another program). For further discussion of Lotus, see infra text accompanying notes 189-97.

6. Thus, im this Comment component works are characterized as "nonreplacing, enhancing works" until the concept of component works is more fully defined at infra Part III. 
computer more powerful, for instance, may be considered a component work.

This Comment argues that such component works should be deemed noninfringing under copyright law. Courts should carefully label component works, applying existing doctrines to deem component works noninfringing. ${ }^{7}$ Copyright law seeks to promote opposmg goalsto reward authors by granting them exclusive rights, and to enhance public knowledge by ensuring access to the authors' creations. Because component works respect the balance between the original author's imterest m rewards and the public's imterest in progress, and because the courts must solve problems not addressed by the 1976 Copyright Act, this Comment argues for an exphicit, judicially recognized exception for component works.

Part I of the Comment provides an overview of copyright law as an imtroduction to copyright law's basic policies and provisions. Part II explores the unrehability of traditional copyright law infringement tests in correctly evaluating nonreplacing works that enhance existing technologies. Part III proposes a component works doctrine which the courts could use to create an exception to the definition of infringing works. The Comment concludes by arguing that this doctrine would promote copyright law's central goals and would be consistent with current copyright law doctrines.

\section{I}

\section{AN INTRODUCTION TO COPYRIGHT LAW}

Copyright law embodies two competing goals: to protect authors (thus providing incentive to create new works) ${ }^{8}$ and to promote public aceess to inforination and knowledge. ${ }^{9}$ The purpose of copyright law is therefore "to create the most efficient and productive balance betwecn protection (incentive) and dissemination of inforination."10 This dichot-

7. I do not address whether component works are themselves copyrightable. I argue only that they do not infringe upon any other person's copyright.

8. The Constitution authorizes Congress " $[t] 0$ promote the Progress of Science and useful Arts, by securing for limited Times to Authors and Inventors the exclnsive Right to their respective Writings and Discoveries." U.S. CoNST. art. I, $\S 8$, cl. 8.

9. Sony Corp. of Am. v. Universal City Studios, Inc., 464 U.S. 417, 429 (1984) (describing the difficult balanee between the interests of authors and society's interest in the free flow of inforination). Note that courts consider the public interest goal to be the inore important. See Zacchini v. Scripps-Howard Broadcasting Co., 433 U.S. 562, 576-77 (1977) (citing United States v. Paramount Pictures, 334 U.S. 131, 158 (1948)).

10. Whelan Assocs. v. Jaslow Dental Lab., Inc., 797 F.2d 1222, 1235 (3d Cir. 1986), cert. denied, 479 U.S. 1031 (1987); see also Harper \& Row, Publishers, Inc. v. Nation Enters., 471 U.S. $539,545-46$ (1985) (purposes of copyright law are to increase public knowledge and give authors a "fair return for their labors"); Hazen, Contract Principles As a Guide for Protecting Intellectual Property Rights in Computer Software, 20 U.C. DAVIS L. REv. 105, 113 (1986) (the ideal copyright 
omy in copyright goals is expressed both in the limited period of copyright protection ${ }^{11}$ and in the determination of what is copyrightable.

These competing goals are embodied in the 1976 Copyright Act. The Act recognizes copyright in hiterary works, musical works (including any accompanying words), and audiovisual works, such as motion pictures or computer video games. ${ }^{12}$ Copyright protection does not extend, however, to any idea, concept, or systein. ${ }^{13}$ This rule is popularly known as the "idea-expression" distinction. ${ }^{14}$ If ideas could be monopolized, copyright law would stifle creativity, directly contradicting copyright law's constitutional mandate. ${ }^{15}$ Thus, in contrast to patent law, copyright law protects only the expression of the idea and not the idea itself. ${ }^{16}$

For example, the story of two star-crossed lovers caught between feuding families is an unprotectable idea, whereas the characters of Romeo and Juliet caught in a conflict between the Capulets and the Montagues is an expression of that idea, and is therefore protectable. ${ }^{17}$ If

law "strikes a fair balance between the creators' right to the fruits of their labors and society's interest in sharing knowledge and technological advancements").

11. Under the Copyright Act of 1976, the period of protection is limited to the life of the author plus 50 years, or a period of 75 years froin the year of first publication of an anonymous work, a pseudonymous work, or a work made for hire. 17 U.S.C. § 302(a), (c) (1988). A work that is not copyrightable or whose copyright period has expired is unprotected and said to be in the "public domain."

12. Id. $\S 102(\mathrm{a})$. This section also extends protection to pantomimes, sculptural works, sound recordings, and dramatic works.

13. Id. $\S 102(\mathrm{~b})$. Nor does copyright protection extend to facts or information revealed in a work. H.R. REP. No. 1476, 94th Cong., 2d Sess., 56 (1976) [hereinafter H.R. REP. No. 94-1476] ("Copyright does not preclude others from using the ideas or information revealed by the author's work."), reprinted in 1976 U.S. CODE CONG. \& ADMIN. News 5659, 5669-70; see Miller v. Universal City Studios, Inc., 650 F.2d 1365, 1371 (5th Cir. 1981) (The current scope of copyright protection "serves an important purpose in copyright law. It provides a means of balaneing the public's interest in stimulating creative activity, as enbodied in the Copyright Clause, against the public's need for unrestrained access to information.").

14. See Whelan Assocs., Inc. v. Jaslow Dental Lab., Inc., 797 F.2d 1222, 1237 (3d Cir. 1986) (the court's goal is to "advance the basic purpose underlying the idea/expression distinction"), cert. denied, 479 U.S. 1031 (1987); Goldstein, Derivative Rights and Derivative Works in Copyright, $30 \mathrm{~J}$. COPYRIGHT SOC'y 209, 218-19 (1983) ("Courts applying the idea-expression distinction to claims of biterary infringenent hold that themes and bare plots are no more than unprotectable ideas ...."); Nimmer \& Krauthaus, Copyright and Software Technology Infringement: Defining Third Party Development Rights, 62 IND. L.J. 13, 41 (1986) (discussing the elasticity of the "idea-expression" distinction).

15. See U.S. CoNST. art. I, § 8, cl. 8.

16. See Baker v. Selden, 101 U.S. 99, 102-05 (1879) (distinguishing between patent law and copyright law protection of ideas). Unlike copyright law, patent protection provides a coinplete monopoly for the inventor in that no one may copy the idea and no one may use the idea or the expression. 35 U.S.C. $\$ \S 154,271$ (1988). As a result, patents are more difficult to acquire. Whereas for copyright protection the author unust show minimal creativity, in patent law the inventor must show the invention to be useful, novel, and non-obvious. Id. $\S \S 101-103$. Moreover, patent protection lasts for ouly 17 years. Id. § 154 .

17. Of course, Shakespeare's play Romeo and Juliet is now in the public domain. Cf. supra note 11 (defining copyright period and "public domain"). 
the idea can be expressed in only one way, however, the expression is said to be "merged" with the idea. Accordingly, "merged" expression is not protected, for to protect it would give the author a monopoly in the idea. ${ }^{18}$

Furthermore, unlike patent law, copyright law does not proscribe a third party's use of a copyrighted work. ${ }^{19}$ For example, in the famous case of Baker $v$. Selden, ${ }^{20}$ the Court held that no one could copy the author's description of his new accounting system, but that anyone could use the accountimg system itself. ${ }^{21}$ Additionally, copyright law does not protect useful articles, since authors may not inonopolize functional creations. So with a functional creation or "useful article" like a belt buckle, only separable aesthetic features may be protected, such as the creative design on the buckle. ${ }^{22}$ Hence, to protect the public interest, copyright law provides only a limited monopoly to authors.

An original author also may create a subsequent work based on her original creation, and she retains the exclusive right to prepare these subsequent works. ${ }^{23}$ These subsequent works are termed "derivative works." The 1976 Copyright Act defines a derivative work as one "based upon one or inore precxisting works," or any "form in which a work may be recast, transformed, or adapted." 24 So, for example, a novehist has the exclusive right to make a movie based on her novel. Similarly, if a toy company wants to make wind-up plastic figures of Mickey Mouse, it must aequire a hicense or other authorization from the Walt Disney Company. In other contexts, however, the concept of a derivative work is inore difficult to define and apply. ${ }^{25}$ For example, what of a cubist

18. See, e.g., Herbert Rosenthal Jewelry Corp. v. Kalpakian, 446 F.2d 738, 742 (9th Cir. 1971) (granting no copyright protection where "idea" and "expression" are not separable).

19. See 17 U.S.C. $\S \S 101,113($ b), (c) (1988); Baker, 101 U.S. at 102-03. Baker explained the distinction:

The difference between the two things, letters-patent and copyright, may be illustrated by

... [the case of medicines]. Certain mixtures are found to be of great value in the healing

art. If the discoverer writes and publishes a book on the subject ... [and copyrights it], he

gains no exclusive right to the manufacture and sale of the medicine; he gives that to the public.

Note that use of a copyrighted work might not include the right to perform it, as that is separately covered under the 1976 Act. 17 U.S.C. § 106(4) (1988).

20. 101 U.S. 99 (1879).

21. Id. at 101-04.

22. Kieselstein-Cord v. Accessories by Pearl, Inc., 632 F.2d 989, 992-93 (2d Cir. 1980); see also Mazer v. Stem, 347 U.S. 201, 213-14 (1954) (allowing copyright of china statuette used as a lamp base).

23. 17 U.S.C. $\S 106(2)$ (1988). The Copyright Act of 1976 gives owners five exclusive rights: reproduction, adaptation, publication, performance, and display. Id. $\S 106$.

24. Id. § 101; see also H.R. REP. No. 94-1476, supra note 13, at 62 ("To be an infringeinent the 'derivative work' must be 'based upon the copyrighted work' . . . . Thus, to constitute a violation ... the infrimging work inust incorporate a portion of the copyrighted work in some form ...."), reprinted in 1976 U.S. CODE CONG. \& ADMIN. NEWS 5659, 5670-71.

25. "In a broad seuse almost all works are derivative works in that in soine degree they are 
painting of a copyrighted photograph, or a computer unlocking program designed to match another author's computer locking program?

Whether a subsequent work is an infringing derivative work ultimately turns on what constitutes an infringing use of an original author's work. To prove copyright infringement, the plamtiff must show that "substantial similarities" exist between his work and the defendant's work. Unfortunately, the substantial similarity test has varied from court to court and over time, ${ }^{26}$ and applies awkwardly to derivative works. Infringement by copying is like piracy: the infringer adds nothing to the stolen expression. Derivative works, on the other hand, are not usually made up of pirated inaterial, but often are creative and original works in their own right. Indeed, consider a movie based upon a novel: creating the movie may require more skill and originality than did writing the novel. Further, though the movie is by definition a derivative, it may in its final version be only slightly similar to the original novel. ${ }^{27}$ Hence, some courts ignore the substantial similarity test and apply a market test to determine infringement. Under that test, if the later work economically harms the author of the original, the later work is an infringing one. ${ }^{28}$

Finally, there is an affirmative defense to a charge of infringeunentthe doctrine of "fair use." Fair uses are deened noninfringing, even if the uses consist of pure copying. The reason for this defense is that a fair use is considered a socially beneficial application of copyrighted inaterial. The 1976 Act provides some examples of "fair use," including criticism, comment, teaching, and research. ${ }^{29}$ Even these beneficial uses, however, may not constitute "fair use" if they cause economic harm to the original author. ${ }^{30}$

derived from pre-existing works .... 'In truth, in literature, in science and in art, there are, and can be, few, if any, things which, in an abstract sense, are strictly new and original throughout.' " $1 \mathrm{M}$. NIMMER \& D. NimMER, Nimmer ON COPYRIGHT §3.01 (1990) [heremafter NIMMER ON CopYright] (quoting Einerson v. Davies, 8 F. Cas. 615, 619 (C.C.D. Mass. 1845) (No. 4436)). Further, one must consider the copyrightability of that part of the original incorporated into the derivative. Id. $\S \S 3.01,13.03[\mathrm{~F}] \mathrm{n} .281$. A work based on the idea of an original work does not infringe, since the idea is not protected. See, e.g., Financial Information, Inc. v. Moody's Inv. Servs., 808 F.2d 204, 205 (2d Cir. 1986), cert. denied, 484 U.S. 820 (1937).

26. Compare Steinberg v. Columbia Pictures Indus., 663 F. Supp. 706, 711 (S.D.N.Y. 1987) (substantial similarity means that "'an average lay observer would recognize the alleged copy as liaving been appropriated froin the copyrighted work' ") (quoting Ideal Toy Corp. v. Fab-Lu, Ltd, 360 F.2d 1021, 1022 (2d Cir. 1966)) with Peter Pan Fabrics, Inc. v. Martin Weiner Corp., 274 F.2d 487,489 (2d Cir. 1960) (substantial similarity means that "the ordinary observer, unless he set out to detect the disparities, would be disposed to overlook them, and regard their aesthetic appeal as the same").

27. Goldstein, supra note 14, at 219-20.

28. See West Publishing Co. v. Mead Data Cent., Inc., 799 F.2d 219, 1227-23 (8th Cir. 1986), cert. denied, 479 U.S. 1070 (1987); see also infra text aecompanying notes 126-37.

29. 17 U.S.C. $\S 107$ (1938).

30. Id. 
Although the basic copyright doctrines delineated above allow the courts to identify infringing works accurately in many contexts, these doctrines lead to illogical outcomes when apphied to nonreplacing, enhancing works. Part II examines these doctrines in greater detail and explains why these outcomes are flawed.

\section{II}

\section{THE INADEQUACIES OF EXISTING INFRINGEMENT DOCTRINES WhEN APPLIED TO NONREPLACING, ENHANCING WORKS}

\section{A. The Definition and Scope of "Derivative Works"}

A "derivative work" is a creation based upon one or more preexisting works. ${ }^{31}$ Under existing copyright law, only the owner of a copyright for a preexisting work may produce a derivative of her work. ${ }^{32}$ Without recognizing the component works issue, several courts have implicitly described nonreplacing works that build on existing teclinology as derivatives, and thus infringements of the original author's exclusive right to prepare derivatives. ${ }^{33}$ Quite simply, under present law, if a nonreplacing work is deemed a derivative, it will be held as infringing.

The courts are mistaken in treating nonreplacing, enhancing works as unlawful derivatives. As commentators have noted, the existing defirition of derivative work is vague and difficult to apply. ${ }^{34}$ As a result, it is often impossible to predict what will or will not be determined a derivative work. Authors of possibly infringing works may therefore play it safe to avoid lawsuits, and decide not to innovate. ${ }^{35}$ This outcome directly contravenes the constitutional mandate of copyright law, which

31. Id. $\S 101$. Note that "derivative work" is sometimes used generally to describe a subsequent work based in part on the original work. Alternatively, the term is often used as a label for a subsequent work that is based in part on the original work and that has been determined to infrimge.

32. Id. $\$ 106(2)$.

33. See cases cited supra note 5 .

34. Hazen, supra note 10, at 116-17, 128-29 (the broad definition makes determining what is a derivative work an uncertain, highly fact-specific inquiry); see also Goldstem, supra note 14, at 211 ("courts have had no general theory to guide them in the evenhanded resolution of cases involving derivative rights and derivative works"); Note, Infringement of the Exclusive Right to Prepare Derivative Works: Reducing Uncertainty, 73 MnNN. L. REV. 1521, 1521 (1989) (authored by Michael Wurzer) (the "substantial similarity" requirement for a derivative work makes the test too vague and unpredictable).

35. See Gemignani, supra note 5, at 393-94 (discussing the application of this argument in the computer software industry). One could argue that the vagne definition of derivative works increases original authors' incentives because they know that fewer people will make works based on their original crcatious. However, the uncertainty of what will be cliaracterized as an infringing derivative does not necessarily enhance original authors' incentives, as there is no predicting how much protection they will have. See Note, supra note 34 , at 1538-41. Thus, clarifying the law in favor of component authors will not further harm the original authors' incentives. 
is "[t]o promote the Progress of Science and useful Arts."36

The case law reflects this vague definition of derivative works. For example, Worlds of Wonder, Inc. v. Vector Intercontinental, Inc. ${ }^{37}$ involved an animated, talking toy bear named Teddy Ruxpin, operated by cassette tapes inserted into his back. The defendant manufactured its own tapes for Teddy Ruxpin, which enabled Teddy to tell fairy tales. The plaintiff had a copyright on the audiovisual effect produced by Teddy Ruxpin, and argued that the defendant's tape infringed this copyright. Noting the similarity of the audiovisual effects of Teddy with his own tapes and Teddy with the defendant's tapes, the court held that the defendant's tape was "at least" a derivative work. ${ }^{38}$

Simply because a subsequent work "almost" violates the original author's exclusive right to make copies does not necessarily make it "at lcast" a violation of the exclusive right to make derivatives. Like the test for copying, the test for a derivative requires a showing of substantial similarity. ${ }^{39}$ The leading copyright law commentator, Professor Melvin Nimmer, has noted that the section 106(2) exclusive right to prepare derivatives "may be thought to be completely superfluous," 40 since the right to inake derivative works will not be infringed unless the right to make copies is also infringed. In fact, Professor Paul Goldstein has noted that "virtually none of the decisions has drawn a principled line capable of separating derivative rights from reproduction rights."41

One result of this uncertainty has been an increasingly broad interpretation of the definition of derivative works. The most expansive interpretation would encoinpass subsequent works with any degree of similarity to the original. Thus, any work that does not violate the prohibition against copying would at least violate the prohibition against derivatives, to the extent there is any similarity between the two creations. Yet the copyright law does not contemplate this result. After all, "in a broad sense almost all works are . . . derived from pre-existing works. ... '[I]n hterature, in science and in art, there are, and can be, few, if any, things which, in an abstract sense, are strictly new and original throughout." "42

36. U.S. CoNST. art. I, $\S 8$, cl. 8. 1986).

37. 653 F. Supp. 135 (N.D. Ohio), later proceeding 1 U.S.P.Q.2d (BNA) 1982 (N.D. Ohio

38. Id. at 140.

39. See Vault Corp. v. Quaid Software, Ltd., 847 F.2d 255, 267 (5th Cir. 1988) ("To constitute a derivative work, 'the infringing work must be substantially similar to the copyrighted work.' ") (quoting Litchfield v. Spielberg, 736 F.2d 1352, 1357 (9th Cir. 1984), cert. denied, 470 U.S. 1052 (1985)).

40. 2 NIMMER ON COPYRIGHT, supra note $25, \S 8.09$ [A].

41. Goldstein, supra note 14 , at 215.

42. 1 NIMMER ON COPYRIGHT, supra notc 25, $\$ 3.01$ (quoting Emerson v. Davies, 8 F. Cas. 615, 619 (C.C.D. Mass. 1845) (No. 4,436)). Indeed, "[the contention]-that 'Progress of Science 
The expansive interpretation of derivative works, therefore, has been widely criticized. ${ }^{43}$ In an address before a gathering of copyright scholars, Professor Ralph Brown declared that the definition of derivative work "is not only expansive, it is still expanding." ${ }^{44}$ He warned that the widening definition has begun to encoinpass ideas and processes-both of which are expressly exempted from copyright protection. ${ }^{45}$ Courts also have broadened the definition of derivative works by erroneously considering the parties' conduct in determining infringement, ${ }^{46}$ and by straining the definition of derivative works to fit existing hicensing agreements. ${ }^{47}$

and useful Arts' cannot occur unless authors and inventors are privileged to build upon earlier progress and earlier innovation-has long been a virtually uncliallenged premise in all branches of the law of intellectual property." Lotus Dev. Corp. v. Paperback Software Int'l, 740 F. Supp. 37, 77 (D. Mass. 1990). The Lotus court quoted Isaac Newton: " "If I have secn further it is by standing on ye sholders of Giants.' " Id. (quoting a letter to Robert Hooke (Feb. 5, 1675/1676), quoted in R. Merton, ON THE Shoulders of Giants: A Shandean Postscript 31 (1965) (articulating the "OTSOG" principle, an acronym for "On The Slioulders Of Giants," and a new catchword in the computcr industry)).

43. See Brown, The Widening Gyre: Are Derivative Works Getting Out of Hand?, 3 CaRdozo ARTS \& ENT. L.J. 1, 2-3, 9-10 (1984) (lecture delivered on Oct. 19, 1983) (noting the adverse effects of the expansive definition of "derivative work"); Gemignani, supra note 5, at 409-10 (arguing that "derivative work" should be interpreted narrowly in the area of software copyright); Goldstein, supra note 14, at 221-23 (stating that copyright law atteinpts to do too much, and citing cases using hiberal definition of "derivative work").

44. Brown, supra note 43 , at 2.

45. Id. at 9-10. Under the 1976 Copyright Act, ideas and processes are statutorily excluded from copyright protection. 17 U.S.C. $\$ 102($ b) (1988).

One common explanation for the unwarranted extension of copyright law is that courts use copyright law to do the work of patent, unfair competition, and trade secret law. Brown, supra note 43, at 2-3; Goldstcm, supra note 14, at 222; cf. Diamond v. Diehr, 450 U.S. 175, $194-98$ (1981) (Stcvens, J., dissenting) (suggesting patcnt law is poorly equipped to protect computer software); Note, Defining the Scope of Copyright Protection for Computer Software, 38 STAN. L. REv. 497, 50306 (1986) (authored by Susan A. Dunn) (arguing that copyright protection is needed to augment patent and trade secret law in order to provide coinplete protection).

But this problein is no longer as acute: "Now that ... patent protection is presently available for virtually all software inventions[,] . . . copyright . . . law will again be able to resume [its] traditional scope[] . . . Maier, Software Protection-Integrating Patent, Copyright and Trade Secret Law, 68 J. PAT. \& TRADEMARK OFF. Soc'y 151, 165 (1987); see also Comment, Federal Intellectual Property Protection for Computer Software Audio-visual Look and Feel: The Lanham, Copyright and Patent Acts, 4 HIGH TECH. L.J. 279, 297-307 (1989) (authored by Gregory J. Wremi) (discussing how patcnts are now available for software).

46. It should not matter whether the author of the derivative work earlier sought a copyright license. Whether or not the alleged infringer feared ler work might be a derivative has no relevance to the definition of a derivative. Goldstein, supra note 14, at 226. But courts have often made this mistake. Professor Goldstein thinks it is "no coincidence that the principal cases establishing broad rights against infringeinent by derivative works characteristically involve situations in which the alleged infringer had at soine earhier point sought a license." Id. at 221. Goldstcin concludes that "[t]he tendency in these cases, always unarticulated because legally irrelevant, is to take the earlier quest for a copyright hicense as evidence that one was needed." Id.

47. Id. at 220-21. Licensing agrecinents may be used for rcasons that are completely irrelevant to the question of copyright. For instance, many firms buy time by paying original authors for rights in the event that the subsequent creation, when coinpleted, may be similar enough to incite an infringement suit. $I d$ at 220 . Such conscientious behavior slould not reshape copyright law, any 
This widening definition may seriously hamper innovation, ${ }^{48}$ particularly in the computer field, where progress occurs incrementally. Better programs come about not from scratch, but through innproveinents of existing programs. Thus, the expansive interpretation of what constitutes a derivative work will inevitably harm the software industry. ${ }^{49}$ The public will be demied improved works, since a reluctance to risk hability will discourage those who improve technology from practicing their craft. Criticizing the expansive definition of derivative work, one commentator warned that "its far reaching potential renders it a tinebomb." The expansive definition overprotects original authors at the expense of the pubhic interest in improved works. Particularly when apphied to nonreplacing works that build on existing technologies and do not harm original authors, the expansive definition inakes hittle sense: expansive protection for original authors is unnecessary when there is no chance of harm.

Moreover, Professor Nimmer finds the right to inake derivatives no different from the right to make copies. ${ }^{51}$ In other words, if a work is not a "copy," it is not a derivative. This is the narrowest possible definition. In the realm of computer programs and other useful works, it is imperative to avoid restraining the march of progress. The narrower the definition of derivative works, the less the confusion of authors, resulting in more works and thus greater public benefit. ${ }^{52}$ Soine use of the original author's work must be permitted. As Zechariah Chafee declares, "[t]he very policy which leads the law to encourage his creativeness also justifies it in facilitating the creativeness of others." 53 Thus, a narrow definition benefits society with minimal harm to the original authors. ${ }^{54}$

Indeed, nonreplacing, enhancing works are not conteinplated under

more than should the shortcomings of patent and unfair competition law. But see Conley \& Bryan, A Unifying Theory for the Litigation of Computer Software Copyright Cases, 63 N.C.L. REV. 563, 597 (1985) (arguing that courts shonld focus on conduct of the parties to determine copyright infringement).

48. Walter, Defining the Scope of Copyright Protection, 14 RUTGERs COMPUTER \& TECH. L.J. 1, 84-85 (1988) (overbroad protection of existing programs destroys incentive to make improvements). Although Gemignani responds to Walter's argument by pointing out that the software industry has continued to thrive, he does not conclude that the hiberal definition of derivative is therefore not harmful. Gemignani, supra note 5, at 397, 409-10.

49. Walter, supra note 48 , at 84-85.

50. Note, The Incompatibility of Copyright and Computer Software: An Economic Evaluation and a Proposal for a Marketplace Solution, 66 N.C.L. Rev. 977, 1015-16 (1988) (authored by Vance Franklin Brown) (discussing the computer software industry in particnlar).

51. 2 NIMMER ON COPYRIGHT, supra note 25, $\$ 8.09$ [A]; see also Brown, supra note 43, at 6. Indeed, another commentator, who advocates expanded rights for original authors, still admits that the "Copyright Act's derivative work provisions refine rather than enlarge the [original author's] rights." Note, supra note 45 , at 511.

52. Gemignani, supra note 5, at 409-10.

53. Chafee, Refiections on the Law of Copyright: I, 45 ColuM. L. Rev. 503, 511 (1945),

54. Indeed, Professor Hazen argnes that original authors deserve inore protection, but he 
the hiteral definition of derivative works in the 1976 Copyright Act. The Act defines derivatives as "work[s] based upon one or more preexisting works ... or any ... form in which a work inay be recast, transformed, or adapted";55 moreover, a "work consistimg of . . . modifications which, as a whole, represent an original work of authorship, is a 'derivative work." "56 This definition implies that a derivative work must stand on its own. In contrast, although a nonreplacing, enhancing work does einploy preexisting inaterial, it inerely tries to improve a part of the original. Thus, in soine sense, a nonreplacing, enhancing work is not a separate work but a part of the original work. It does not, as a whole, represent an original work of autlorship since it is dependent on the original work -it cannot stand on its own.

Most importantly, the nonreplacing, enhancing work sliould not be defined as a derivative, for it typically does not harm the original autlior. This harm is what the exclusive riglit to prepare derivatives intends to prevent. All the examples of derivative works given in the Act-"translation, musical arrangement, dramatization, fictionalization, motion picture version, sound recording, art reproduction, abridgeinent, condensation"S7_-can stand on their own and replace the original work. Nonreplacing, enhancing works cannot. Since tliey do not harm original autliors, they sliould not be treated like derivative works.

\section{B. The Substantial Similarity Test for Infringement}

To prove copyright infrimgeinent, a plaintiff must show that the defendant's work is "substantially similar" to the plaintiff's copyriglited work. The judge or jury coinpares tlie two works, and must decide "whetlier an average lay observer would recognize the alleged copy as having been appropriated froin the copyrighted work." 58 If so, then the new product is deemed substantially similar to the original work, and is thus infrimging. ${ }^{59}$ Yet the substantial similarity test is imsplaced where a work is based on, but does not copy, an original work. The test is inappropriate since the new work is dissimilar to the original work. ${ }^{60}$ It

would provide it by means of contracts and licensing agreements, not by unduly expanding copyright law. See Hazen, supra note 10, at 128-29.

55. 17 U.S.C. $\S 101$ (1988).

56. Id.

57. Id.

58. Ideal Toy Corp. v. Fab-Lu Ltd., 360 F.2d 1021, 1022 (2d Cir. 1966); see also supra notes 26-28 and accounpanying text.

59. The plaintiff must also demonstrate that the defendant had access to the plaintiff's work, in order to disprove any possibility of the defendant's independent creation of a similar work-which would not be a copyright violation. See, e.g., Gaste v. Kaiserman, 863 F.2d 1061, 1066 (2d Cir. 1988) ("Because copiers are rarely caught red-handed, copying lias traditionally been proven circumstantially by proof of access and substantial similarity.").

60. Note, supra note 34 , at 1534 ("A derivative work by its nature is dissimilar to the original 
makes little sense to apply a similarity test that is designed to determine if something is a copy, in order to determine if something dissimilar (such as a nonreplacing, enhancing work) is infringing.

Midway Manufacturing Co. v. Artic International, Inc. ${ }^{61}$ provides a useful illustration. In this case, the defendant created a computer chip for insertion into the plamtiff's video game, to make it play faster. The plaimtiff alleged infrimgennent of its audiovisual copyright, which protects the game's sounds and graphics. The court imphicitly apphed the substantial similarity test: the audiovisual display of the video game with the defendant's chip was substantially similar to the game's display without tle chip, so the chip was deemed an infringing derivative. ${ }^{62}$ But the defendant's computer chip itself had no audiovisual display to compare with the video game's copyrighted audiovisual display. The defendant's work was simply a sequence of coinputer code that relied upon the plaintiff's work to produce an audiovisual display. In essence, the court analyzed the similarity of a coinputer chip (an object) to an audiovisual display (a series of sights and sounds). Since these works are dissimilar, the substantial similarity test is ill-suited to determine infrimgeinent. ${ }^{63}$

In addition, the substantial similarity test fails in two respects to promote original authors' incentives. First, the unpredictability of such a clumsy tcst prevents autliors from accurately gauging the extent of protection for new works. ${ }^{64}$ There is little incentive if an author cannot rely upon the reward. Second, dissimilar works that destroy the demand for the original are noninfringing under the substantial similarity test. For example, in Vault Corp. v. Quaid Software, Ltd., ${ }^{65}$ the defendant was sued for marketing a computer program that unlocked the plaintiff's coinputer locking program. Because it had a different (indeed, an opposite) function, the defendant's program was not substantially similar. ${ }^{66}$ Thus, there was no infringement. ${ }^{67}$ The problem, of course, is that the defendant's program destroys the market for the plaintiff's work. Few

work and, therefore, using 'substantial similarity' as the basis of the test for infringement ... creates uncertainty.").

61. 547 F. Supp. 999 (N.D. Ill. 1982), aff'd, 704 F.2d 1009 (7th Cir.), cert. denied, 464 U.S. 823 (1983).

62. Id. at 1013-14. The court must have applied this test, since it merely noted that the displays were similar and then found that the defendant had infringed.

63. See Note, Copyright Infringement of Computer Programs: A Modification of the Substantial Similarity Test, 68 MINN. L. REv. 1264, 1292-94 (1984) (authored by Howard Root) (arguing that we must reevaluate the substantial similarity test: simce software technology progresses by making imcremental changes to existing software, creative innovations may still fail the test).

64. Note, supra note 34, at 1535.

65. 847 F.2d 255 (5th Cir. 1988).

66. The court found neither the quantity nor the quality of the copying was enough to result in substantial similarity. Id. at 267.

67. Id. at 268. But cf. Addison-Wesley Publishing Co. v. Brown, 223 F. Supp. 219 (E.D.N.Y. 1963) (copyright to textbook infringed by publication of answer guide to problems in textbook); 
people will buy a locking program when anyone with the defendant's product can unlock it. The substantial similarity test fails to protect the original author's financial incentives to create, even though copyright law is supposed to promote those incentives.

\section{The Look-and-Feel Doctrine}

Soine courts have begun to use the "look-and-fecl" doctrine to find nonreplacing, enhancing works infringing. The look-and-feel doctrine, which originated in Roth Greeting Cards v. United Card Co., ${ }^{68}$ is a method of deinonstrating substantial similarity. In Roth, the court found that the defendant's allegedly copied greeting cards were substantially similar to the originals in "total concept and fecl," though not in any proteetable expression. ${ }^{69}$

Significantly, this doctrine has also been extended to the computer field, where it has inet with heated debate. In Whelan Associates v. Jaslow Dental Laboratory, Inc., ${ }^{70}$ the defendants hired the plaimtiff to create a coinputer program to run a dental laboratory. After the plamtiff created the program, the defendants inade their own dental laboratory program without directly copying any of the plaimtiff's program code. The court nonetheless found infringement because the defendants had copied the structure, sequence, and organization of the plaimtiff's program. ${ }^{71}$ In Broderbund Software, Inc. v. Unison World, Inc., ${ }^{72}$ the court extended the look-and-feel doctrine further, holding that the defendant was hable for emulating the look and feel of the audiovisual screen displays of the plaintiff's program. ${ }^{73}$

\section{The Look-and-Feel Doctrine Is Fundamentally Misguided and Rests on Faulty Premises}

The look-and-feel cases usually arise with audiovisual copyrights, for creations such as video game displays, since the look and feel of an audiovisual display are inore tangible than, for example, the look and feel of a novel. Indeed, look-and-feel doctrine is especially relevant to the computer context, since the Copyright Office has decreed that a copyright on a program also protects the audiovisual output of that program. ${ }^{74}$ Thus, the look and feel of every copyrighted program's

Procter \& Gamble Co. v. Moskowitz, 127 U.S.P.Q. (BNA) 523 (E.D.N.Y. 1960) (copyright to contest entry blank infringed by publication of contest answers).

68. 429 F.2d 1106 (9th Cir. 1970).

69. Id. at 1110 .

70. 797 F.2d 1222 (3d Cir. 1986), cert. denied, 479 U.S. 1031 (1987).

71. Id. at $1238-39,1246-48$.

72. 648 F. Supp. 1127 (N.D. Cal. 1986).

73. Id. at 1137 .

74. Manufacturers Technologies, Inc. v. Cams, Inc., 706 F. Supp. 984, 990-91 (D. Conn. 1989) 
audiovisual output is potentially protected.

The broadest interpretation of the look-and-feel doctrine was presented in Broderbund, ${ }^{75}$ where the district court protected the look and feel of the audiovisual display of the plaintiff's programs. ${ }^{76}$ The court alleged that its holding rehed upon Whelan. ${ }^{77}$ Yet Whelan had found that a prograin copyright protected the structure, sequence, and organization of that program, ${ }^{78}$ but did not protect the audiovisual display. Thus, Broderbund rests upon faulty premises. As one court explained:

The Broderbund court extended the reach of Whelan by equating coinputer program copyright protection for the structure, sequence and organization of a program with protection of the screen outputs. However, the Whelan court said only that, as an evidentiary matter, that screen outputs could be indirect and inferential evidence useful in establishing copying of the underlying computer program. ${ }^{79}$

Yet even Whelan's more limited protection of programs' structure and sequence is under attack. For exainple, in Digital Communications Associates, Inc. v. Softklone Distributing Corp. ${ }^{80}$ the court rejected the look-and-feel analysis. It held that the plaintiff must show evidence of copying of source and object codes, ${ }^{81}$ as well as copying of the structure, sequence, and organization of a program. ${ }^{82}$ Thus, the Softklone court

(citing Copyright Office Notice on Computer Screen Registration, 36 Pat. Trademark \& Copyright J. (BNA) 152, 155 (1988)). The Copyright Office considers screen displays and their underlying programs a "single work" to be registered on a single application form. See 37 C.F.R. 202.3(b)3; see also Note, Single Copyright Registration for Computer Programs: Outdated Perceptions Byte the Dust, 54 BRoOKLYN L. REV. 965, 968 (1988) (authored by Steven M. Levy) (approving of this development as more practical). The concept of a screen display and its underlying application as a single work is a break from past practice. See, e.g., Williams Elecs., Inc. v. Artic Int'l, Inc., 685 F.2d $870,872-73$ (3d Cir. 1982) (treating as separate works a video game's audiovisual effects and its coinpnter program).

75. Broderbund Software, Inc. v. Unison World, Inc., 648 F. Supp. 1127 (N.D. Cal. 1986)

76. Id. at 1137.

77. Id. at 1133 (citing Whelan Assocs. v. Jaslow Dental Lab., Inc., 797 F.2d 1222, 1224 n.1, 1240 (3d Cir. 1986), cert. denied, 479 U.S. 1031 (1987)).

78. Whelan, 797 F.2d at 1239-40.

79. Manufacturers Technologies, Inc. v. Cams, Inc., 706 F. Supp. 984, 992 (D. Conn. 1989) (citation omitted). One commentator suggests courts slould either compare the computer source codes for substantial similarity, or observe the sounds and screen displays to determime infringement. Perelman, Proving Copyright Infringement of Computer Software: An Analytical Framework, 34 COPYRIGHT L. SYMP. 99, 134-35 (1987).

80. 659 F. Supp. 449 (N.D. Ga. 1987).

81. Source code is the computer program written in programming language. Object code is the source code translated imto the bimary number language that the computer reads.

82. Softklone, 659 F. Supp. at 455-56. The status of Softklone's lolding is unclear today, for it considered the effect of a program copyright at a time when audiovisual and program copyrights were considered separate. Cf. supra note 74 and accompanying text (describing Copyright Office's new policy considering these aspects of the software together). 
did not protect the look and fecl of the plaintiff's audiovisual display, but merely the actual expressive elements displayed.

In Synercom Technology v. University Computing Co., ${ }^{83}$ the defendant copied the logic, sequence, and arrangement of the plaintiff's input formats. ${ }^{84}$ The court held that while the formats were copyrightable, the sequence and arrangement were merely ideas, and not part of the protectable expression. ${ }^{85}$ In contrast, under a look-and-feel test the court might have found the imput formats infringing on the basis of similar sequence and arrangement.

The Synercom court reasoned that the sequence and organization were ideas, rather then expression, by using the exainple of the "figure$H^{\prime \prime}$ pattern of an automobile shift stick. ${ }^{86}$ The pattern chosen is arbitrary, but once chosen it is the only one that will work. The pattern, like the input format, may be expressed in different ways, such as with a photograph, a diagrain, or a description in a driver's manual. As the court noted: "Each of these expressions may presumably be protected through copyright. But the copyright protects copying of the particular expressions of the pattern, and does not prohibit another manufacturer from marketing a car using the saine pattern. Use of the saine pattern might be socially desirable, as it would reduce the retraining of drivers."87 Similarly, a photograph or description of an audiovisual display is protected, but the look and feel, or the strncture and sequence of the display, is not.

Further dissatisfaction with the look-and-feel doctrine is reflected in Plains Cotton Cooperative Association v. Goodpasture Computer Service, Inc., ${ }^{88}$ where the Fifth Circuit followed Synercom rather than Whelan. The court rejected the plaintiff's claim of "organizational" copying of his cotton inarket computer prograin, finding that many of the structural similarities in the two prograins were dictated by the features of the cotton market itself. ${ }^{89}$ The court thus "decline[d] to hold that those patterns could not constitute 'ideas." "90

83. 462 F. Supp. 1003 (N.D. Tex. 1978). The Whelan court admitted its holding was "at odds with Judge Higginbotham's scholarly opinion [in Synercom]." Whelan, 797 F.2d at 1239.

84. "In using a program one must have a format for input so that the imput of data and the instruction to the computer are compatible with its program." Synercom, 462 F. Supp. at 1005.

85. Id. at 1012-14. The court also mentioned that if the sequence of the formats were expression, then the alternative holding would be that the expression and the idea were merged, and the formats thus were not copyrightable. Id. at 1014. But the court did not limit its holding to cases where idea and expression were merged. "[T]here are many more possible choices of coinputer formats, and the decision among them more arbitrary [than a stick shift pattern], but this does not detract from the force of the analogy." Id. at 1013.

86. Id. at 1013.

87. Id.

88. 807 F.2d 1256 (5th Cir.), cert. denied, 484 U.S. 821 (1987).

89. Id. at $1260-62$.

90. Id. at 1262. Even though the Plains Cotton court favored Synercom over Whelan, it inay have limited Synercom's holding by applying it to a situation where market factors determined the 
It is clear, then, that many courts have been critical of Whelan and the look-and-feel test. ${ }^{91}$ Commentators, too, have roundly criticized Whelan. For example, Professor Nimmer writes that Whelan's

sweeping rule and broad language extend copyright protection too far. Providing protection for such amorphous concepts as the "overall structure" of a program, without considering whether such a structure is protectable under traditional copyright theories, increases the risk of granting copyright holders protection on a par with that provided to patent holders. Such a result could be disastrous . . . .92

Not only is Whelan's result harmful, its logic is misguided. It separated idea from expression by defining the purpose of the work as the idea, and everything not necessary to that purpose as protectable expression of the idea. ${ }^{93}$ Thus, in Whelan, the purpose of the program was to operate a dental laboratory. Everything else was protectable expression. Whelan erred in assuming that a computer program has ouly one idea. ${ }^{94}$ On the contrary, every program embodies several functions, and thus several ideas, some more abstract, some inore specific. The outcome under Whelan thus depends on which idea the court thinks the program embodies. This arbitrary result only worsens the existing uncertainty.

Whelan also includes as expression the way the program carries out a certain function. ${ }^{95}$ This could reasonably be imterpreted to say that a

structure; that is, there were few or no other ways of expressing the structure. Id. This comes close to the concept of "merger"-an expression of an idea is not protected when there is only one way to express it-a concept that Synercom did not require.

91. See, e.g., Telemarketing Resources v. Symantec Corp., 12 U.S.P.Q.2d (BNA) 1991, 1996 (N.D. Cal. 1989) (finding a computer program's look and feel (functions, editing screen, menu bar, pull-down windows, and color scheme) merely "idea," and not protectable expression); Data E. USA, Inc. v. Epyx, Inc., 862 F.2d 204 (9th Cir. 1988) (refusing to protect the look and feel of a karate video game). But see Lotus Dev. Corp. v. Paperback Software Int'l, 740 F. Supp. 37, $63-68$ (D. Mass. 1990) (protecting the user interface of a spreadsheet program).

Presently, two big look-and-feel cases are pending. Lotus has sued a competitor who produced an independently programmed version of Lotus' 1-2-3 spreadsheet program. Lotus Dev. Corp. v. Mosaic Software, Inc., No. 87-74K (D. Mass. filed Jan. 12, 1987). Apple is suing Microsoft for marketing a program that contains an Apple-like overlapping window display. Apple Computer, Inc. v. Microsoft Corp., No. C88-20149-WWS (N.D. Cal. filed Mar. 17 1988); see Abramson, Look and Feel of Computer Software, CASE \& COM., Jan.-Feb. 1990, at 3, 3-4.

92. 3 NIMMER ON COPYRIGHT, supra note $25, \S 13.03$ [A][1][d].

93. Whelan, 797 F.2d at 1236.

94. 3 N1MMER ON COPYRIGHT, supra note 25, § 13.03[F][1] ("The crucial flaw in this reasoning is that it assumes that only one 'idea,' in copyright law terms, underlies any computer program, and that once a separable idea can be identified, everything else must be expression.").

95. Whelan, 797 F.2d at 1239 . Another case from about the same time went the other way. See Q-Co Indus., Inc. v. Hoffman, 625 F. Supp. 608 (S.D.N.Y. 1985). In $Q$-Co, the two parties had each developed a computer disk to turn a television into a teleprompter. The display effects were similar, but the underlying computer programs were different. One program was for an IBM computer, and the other for an Atari computer. The court found no infringement, even though the defendant had copied the function of the plaintiff's program, since this was idea, not expression. Id. at 616; see also Synercom Technology, Inc. v. Umiversity Computing Co., 462 F. Supp. 1003, 1013 (N.D. Tex. 1978) (use or function elements not copyrightable). 
copyright, which covers expression, also covers a process or a procedure. ${ }^{96}$ Yet the Copyright Act explicitly rejects protection for any system, process, or procedure. ${ }^{97}$ Thus, in applying look-and-feel to the structure, sequence, and organization of a computer program, the Whelan court has overextended copyriglit law by violating the express terms of the Copyright Act. ${ }^{98}$

Professor Pamela Samuelson argues tliat the look-and-feel doctrime, invented by two commentators, has virtually no standing in copyright law. ${ }^{99}$ The "total-concept-and-feel doctrime," from which tlie look-andfeel doctrime derived, was desigued to coinplement a detailed, analytic dissection test, so tlie court would not miss tlie forest for the trees. Thus, it is wrong to use by itself even the inore limited total-concept-and-feel doctrine. Yet the courts liave done just this. Indced, the total-conceptand-feel doctrine was intended only for fanciful or artistic works, and not functional works like computer programs. Further, functional writings can receive only "thin" copyrights, which protect only against nearly identical copying. Thus, she concludes tliat since the user interface is functional and not fanciful, it sliould not receive total-concept-and-feel protection (let alone look-and-feel protection).

Additionally, powerful policy reasons argue against tlie "look-andfeel" or "total-concept-and-feel" doctrine. First, the doctrines threaten the idea-expression distinction. Nimmer warns tliat

the touchstone of "total concept and fcel" threatens to subvert the very essence of copyright, namely the protection of original expression. "Concepts" are statutorily ineligible for copyriglit protection; for courts to advert to a work's "total concept" as the essence of its protectible character seeins ill-advised in the extreme. ${ }^{100}$

Second, as Nimmer argues, the uncertainty created by tlie look-and-

96. Gemignani, supra note 5 , at 404 .

97. 17 U.S.C. $\S 102(b)$ (1988).

98. See Forsten, It Walks and Talks Like my Duck, So How Come It's Not Infringement?: The Case Against "Look and Feel" Protection for Computer Programs, 70 J. PAT. \& Trademark OfF. Soc'y 639, 646 (1988) (arguing that the Commission on New Technological Uses of Copyrighted Works, which Congress commissioned to report on changing technology and the Copyright Act, disapproved of the look-and-feel doctrine); see also Sutton, Equities, Evidence, and the Elusive Scope of Copyright Protection for Computer Software, 69 J. PAT. \& TRADEMARK OFF. Soc'y 551, 564 (1987) (noting that "effort" does not make a work copyrightable, and arguing that "the Whelan court relied too lieavily on the anount of effort put into developing the arrangement of the computer program").

99. Samuelson, Why the Look and Feel of Software User Interfaces Should Not Be Protected By Copyright Law, 32 CoMM. of ACM 563 (1989); see also Kepner-Tregoe, Inc. v. Carabio, 1979 Copyright L. Dec. (CCH) \ 25,107, at 15,638-39 (E.D. Micls. 1979) (arguing "total concept and feel" apphicable to artistic works, not useful arts).

100. 3 NIMMER ON COPYRIGHT, supra note 25, § 13.03[A][1][c]; see also Stallman \& Garfinkel, Viewpoint Against User Interface, 33 CoMM. of ACM 15 (1990) (articulating ten reasons to oppose look-and-feel protection). 
feel cases hampers development in the computer field, as no clear infringeinent guidelines exist. Developers may therefore avoid expansion or improvements of existing programs. ${ }^{101}$ In addition, if the look-andfeel doctrine persists, it might weaken severely U.S. software developers' ability to compete with foreign developers. The European Econormic Community, in atteinpting to define a consistent copyright doctrine, has proposed limitmg or even abolishing the look-and-feel doctrine by denying protection for computer interfaces. ${ }^{102}$ If this proposal passes, software development in EEC countries could progress at a inuch faster rate than it does in the United States.

Third, the look-and-feel doctrine is objeetionable in hight of the economic incentive policy that underlies copyright law. The look and feel of a program is not easily "copied." A developer must spend appreciable time and effort to write a program that copies the feel of the original program. Developing does not fit the classic inold of copying, where someone simply duplicates a program, and should not be treated as such. ${ }^{103}$

Fourth, requiring a coinpletely dissimilar look and feel for different coinputer programs is wasteful, simce learning to use a coinputer program involves training costs. Once the user has expended the costs, he has hittle imcentive to switcli to a competing program that would require retraining. ${ }^{104}$ This "lock-m effect" could "easily result in a virtual inonopoly if one particular program or approach were to gain widespread acceptance." ${ }^{105}$ Compatibility poses a related problem: if inost coinputer users have one systein, others must use that system or else they will be unable to communicate with the majority. ${ }^{106}$ This too builds in a monopoly for the first inventor. The danger in providing patent monopoly protection through copyright law is obvious. Patent law limits the monopoly to seventeen years. Conversely, copyright law would not only fail to require utility, novelty, and non-obviousness, it would extend the monopoly for about seventy-five years.

Finally, the cases establishing the look-and-feel doctrine often appear to be based upon the perceived bad faith of the defendant, rather tlian on principles of copyright law. As one commentator noted: "One

101. 3 NIMMER ON COPYRIGHT, supra note $25, \S 13.03[$ A] [1][d].

102. See Draft Report on a Proposal for a Council Directive on the Legal Protection of Computer Programs, Eur. PARL. Doc. (No. C3-56) (Committee on Legal Affairs and Citizens' Rights) art. 1, amend. II, at 5 (Nov. 20, 1989).

103. Forsten, supra note 98 , at $660-61$.

104. See, e.g., Synercon Technology, Inc. v. University Computing Co., 462 F. Supp. 1003, 1008 (N.D. Tex. 1978) (defendant's program was written to be conipatible with plaintiff's format so that users could switch to the new program with minimal training).

105. Forsten, supra note 98 , at 661 .

106. Id. at 662; see also Menell, Tailoring Legal Protection for Computer Software, 39 STAN. L. REV. 1329, 1340-45 (1987) (discussing this problem of externalities). 
recurring theme in Whelan . . . and Broderbund which is absent from Synercom, Plains Cotton, and Softklone, seems to be an eleinent of bad faith in the defendant's behavior."107 In Whelan and Broderbund the plaintiffs established that the parties had previous contractual dealings, and that the defendants had generous access to the plaintiffs' program. In the other cases, the plaintiffs failed to prove that the defendants had such access to the programs. ${ }^{108}$ Thus, where the court wants to punish the defendant but traditional copyright law permits the behavior, courts have used the look-and-feel test as a last resort to punish the defendant. If courts do indeed focus on the conduct of the defendants in reaching their decisions, "it is inappropriate and hurts those not guilty of such conduct [by not] allowing thein to develop competing prograins."109

\section{The Look-and-Feel Doctrine Is Particularly Inappropriate for Nonreplacing, Enhancing Works}

Courts have used the look-and-feel doctrine in the audiovisual context to find nonreplacing, enhancing works infringing. The application of the doctrine to these works is particularly inappropriate. Since these works cannot function on their own, they produce no audiovisual display and thus their look and feel cannot be compared to that of the original work. The author of the enhancing work does not produce a copy of the original work, but rather copies only the idea of the original work and provides soinething to go with it.

The two Teddy Ruxpin cases illustrate this problem with the lookand-feel doctrine. ${ }^{10}$ Teddy Ruxpin, the talking toy bear, is animated by

107. Forsten, supra note 98 , at 663.

108. Id. at 663-64 (access described in Broderbund Software, Inc. v. Unison World, Inc., $648 \mathrm{~F}$. Supp. 1127, 1136 (N.D. Cal. 1986), and Whelan Associates v. Jaslow Dental Laboratory, Inc., 797 F.2d 1222, 1232 (3d Cir. 1986), cert. denied, 479 U.S. 1031 (1987)). One commentator asserts that the inconsistent decisions are acceptable. He argues that each court balances the coinpeting motives on a case-by-case basis. If the work is worth protecting, the court calls it expression. If it is not, the court will deem it idea. See Pilarski, User Interfaces and the Idea-Expression Dichotomy, or, Are the Copyright Laws User-Friendly?, 15 AIPLA Q.J. 325, 347-53 (1987).

109. Forsten, supra note 98 , at 664 . Forsten suggests that other types of actions, such as fraud, misappropriation, or unfair competition, would be preferable means of seeking relief from bad-faith defendants. Id.; see also infra note 179. Lotus Development Corp. v. Paperback Software International, 740 F. Supp. 37 (D. Mass. 1990), is also a look-and-feel case, though Judge Keeton disapproved of that phrase, see id. at 62-63. But Lotus involved copying of the entire user interface, not inerely parts of it. Morcover, it too involved bad faith on the part of the defendant. Paperback attempted to copy exactly Lotus' 1-2-3 spreadsheet program to usurp Lotus' market, and Paperback even boasted about that fact in its hiterature. "[Our spreadsheet] is a feature-for-feature workalike for $1-2-3 . .$. It has the same command tree. It allows the same kind of calculations, the same kind of numerical information. Everything 1-2-3 does, [our program] does." VP-Planner Manual, at 1.11, quoted in Lotus, $740 \mathrm{~F}$. Supp. at 69-70. For further discussion of Lotus, see infra text accompanying notes $189-97$.

110. Worlds of Wonder, Inc. v. Veritel Learning Sys., 658 F. Supp. 351 (N.D. Tex. 1986) (order granting preliminary injunction); Worlds of Wonder, Inc. v. Vector Intercontinental, Inc., 653 F. 
motors im his eyes, nose, and mouth, a modified cassette player and speaker, and programmed cassette tapes imserted into his back. The cassette tape contains two tracks, similar to stereo cassette tapes. One track, for audio, contains songs and stories about Teddy Ruxpm. The other track, the command track, activates the motors in Teddy's face. The two tracks are synchronized so that the eyes, nose, and mouth inove in a lifelike fashion as he sings and tells stories. The defendants marketed their own two-track cassette tapes to be inserted into Teddy Ruxpin, enabling Teddy to tell traditional fairy tales. ${ }^{111}$

The audiovisual display of Teddy Ruxpm was of a talking, animated bear. Since the plaintiff copyrighted Teddy Ruxpin as an audiovisual work, it was this audiovisual display that the plaintiff protected. ${ }^{112}$ If the defendants had marketed their own ammated bear and tapes, the court could have compared the audiovisual display of Teddy Ruxpin with the audiovisual display of the competing bear. ${ }^{113}$ But the defendants' product was simply a cassette tape, and its audiovisual display required the inachinery of Teddy Ruxpin. The look-and-feel test therefore could not adequately evaluate the two products.

The Teddy Ruxpin cases were brought against two separate defendants, one in Ohio and one in Texas. Each court found that the defendant's audiovisual display was substantially similar to the plaintiff's, based on the total concept and feel of the two works. ${ }^{114}$ Each court reached its deeision by comparing the audiovisual effect of the defendant's tape with the audiovisual effect of the plaintiff's tape. Neither court perceived the problem that the defendant's work, being a component work, had no audiovisual display of its own. ${ }^{115}$ As a result, each court employed circu-

Supp. 135 (N.D. Ohio) (order granting preliminary injunction), later proceeding 1 U.S.P.Q.2d (BNA) 1982 (N.D. Ohio 1986) (order granting permanent injunction).

111. Veritel, 658 F. Supp. at 353; Vector, 653 F. Supp. at 137.

112. Veritel, 658 F. Supp. at 353; Vector, 653 F. Supp. at 138.

113. In fact, two Califorma companies attempted to import and sell unauthorized copies of Teddy Ruxpin. Worlds of Wonder eventually settled a lawsuit it had filed against thosc companies. Teddy Ruxpin's Maker Resolves a Lawsuit, L.A. Times, Dec. 23, 1986, § 4, at 2, col. 5.

114. Veritel, 658 F. Supp. at 355 (Texas); Vector, 653 F. Supp. at 139-40 (Ohio).

115. Discerning copyright scholars might argue that the Teddy Ruxpin cases raise the issue of contributory infringement. Coutributory infringenent occurs where the defendant markets an item that permits users to infringe unlawfully the plaintiff's copyright. For example, selling a videocassette recorder (VCR) is not copying copyrighted movies, but a VCR does allow its owner to copy the copyrighted movies. Because it would be impractical to sue every individual VCR owner who copied a copyrighted movie, the law permits the movie copyright owner to sue the VCR manufacturer, who makes possible the unlawful behavior. See Sony Corp. of Am. v. Umiversal City Studios, Inc., 464 U.S. 417 (1984) (finding no contributory infringement because VCRs are capable of substantial noninfringing uses).

In the Teddy Ruxpin cases, however, the buyer is not able to create a copy of the original work (i.e, a new Teddy Ruxpin). The cassette tapes the defendants sold were not machines enabling the buyer to copy the plaintiff's bear. Indeed, buyers already owned the machine: Teddy Ruxpin himself. Although the defendants' tapes do produce a new audiovisual display, the display relies 
lar reasoning in attempting to discern and compare two audiovisual displays from a single bear. Simce the same bear was used to compare the defendant's and the plaintiff's tapes, the appearance, motions, gestures, and voice were obviously identical. ${ }^{116}$ Each court simply watched one bear perform twice and declared the displays the same.

The courts' flawed reasoning would restrict nonreplacing, enhancing works. These works will always be somewhat similar to the original in look and feel, since the nonreplacing, enhancing work is intended to "go with" the original. This compatibility, however, is precisely why the new works should be deemed noninfringing. By building on the original work, the new works minimize econoumic harm to the original author: one must still purchase Teddy Ruxpin to utilize the defendants' tapes. ${ }^{117}$

upon the original Teddy Ruxpin doll. Since one must always use the original to create the new audiovisual display, the original author's work remains valuable. In contrast, a VCR produces a new recording of the copyrighted movie, so that one no longer needs the original. Note that if the defendants sold an animated bear without tapes, this would be contributory infringeinent. It would allow a buyer to use the Teddy Ruxpin tapes to make an unlawful copy of Teddy Ruxpin. Of course, this would not constitute a coinponent work, since the substantial part of the original whole was copied. See infra note 161 .

One explanation for the Teddy Ruxpin cases is that the courts implicitly found that the tapes contributorily infringed. Although the tape itself has no audiovisual display, when placed in Teddy Ruxpin by the user it produces a new and infringing display. In fact, in a later proceeding in the Ohio Teddy Ruxpin case, the court summarily "found" contributory infringeinent. The court purported to derive this conclnsion froin the earher opimion, where the issue was not addressed. Worlds of Wonder, Inc. v. Vector Intercontinental, Inc., 1 U.S.P.Q.2d (BNA) 1982, 1983 (N.D. Ohio 1986).

This finding seems to fall outside the intended scope of contributory infringement, however. At soine point, there must be a de minimis limit to contributory infringeinent. "Merely enabling" the user to infringe cannot be enough. Assume the Sony court had found that VCRs contributorily infringe. (Recall the reason the Court did not so find is that it found an exception: VCRs have substantial noninfringing uses, a finding the court of appeals had rejected. Sony, 464 U.S. at 428.) Is Sony's supplier of VCR parts also a contributory infringer? The parts unquestionably "enable" the loine user to tape (i.e., copy) copyrighted shows. With no de minimis rule, the copyright owner of the sliow could sue the inanufacturer of the plastic "play" button on the VCR control panel. See generally 3 NIMMER ON COPYRIGHT, supra note 25, \$ 12.04[A][2][b] (discussing the uncertain terrain of contributory infringement).

116. Veritel, 658 F. Supp. at 355; Vector, 653 F. Supp. at 139-40. Although the voice could have been different, the possible difference was limited by the capability of the speakers in Teddy's mouth. Similarly, the motions and gestures could not have changed much, since the range of inotion depended on Teddy's mecharics.

117. The harm to the plaintiff from the defendants' tapes was probably minimal. Sales of the Ruxpin bear quickly declined anyway, due to coinpetition froin other talking toys. Brandt, Worlds of Wonder: From Wall Street Charmer to Chapter 11, BuS. WeEk, Mar. 21, 1988, at 74. Perhaps a new series of tapes would have rekindled interest. The only harm to the plaintiff was that it too sold tapes for the bear separately. See Stevenson, The Selling of Toy "Concepts," N.Y. Times, Dec. 14, 1985 , $\S 1$, at 33, col. 3. These would lave had to coinpete with the defendants' tapes.

In court, the plaintiff successfully argued that it was harmed because the defendants' tapes told stories that did not involve Teddy and his world, in a seuse diluting his image. Veritel, 658 F. Supp. at 356. If this were truly harmful, of course, the plaintiff could still foreclose marketing of the component work by showing substantial harm. Moreover, the plaintiff might then have had a 
The similar look and feel, in fact, is what allows the works to avoid harming the original author.

\section{The Fair Use Doctrine}

Even if the creator of a new product has directly copied the original creator's expression, the infringement may be ignored if the new use is a "fair use." The fair use doctrine allows educational and noncommercial uses. Nonetheless, even if the use is fair, the defendant still will be enjoined if the plaintiff shows he will be economically harmed by the proposed "fair" use. Thus, the fair use doctrine includes a harm exception, ${ }^{118}$ which focuses on the inarket effects of the alleged infringeinent. ${ }^{119}$ So unless the educational or beneficial use harms the deinand for the original author's work, a fair use can exist. ${ }^{120}$

Many nonreplacimg, enhancing works thus inay be deemed noninfringing under the fair use doctrine. In New York Times Co. v. Roxbury Data Interface, Inc., ${ }^{121}$ for example, the court used the fair use doctrine to deem a nonreplacing work noninfringing. In Roxbury, the defendants created a personal naine index to the plaintiff's New York Times Index. The court found the defendants' index noninfringing, applying the reasoning behind nonreplacing works. It declared that the defendants' inclex would "serve the public interest in the dissemination of information." 122 Then, the court found the clefendants' work dependent and nonreplacing: "Since clefendants' index carries citations only to the New York Times Index, defendants' index is useless unless its user has access to the Times Index . . . . [P]urchase of defendants' index in no way supersedes the need for plaintiff's inclex; indeed, both the viability and the utility of the [defendants'] index depends entirely on the Times Index." ${ }^{123}$ Since there was no replacing use-users would still need to

successful dilution suit under trademark law. Cf. infra note 179 (status as component work does not preclude actions under related doctrines).

118. See 17 U.S.C. $§ 107(4)$ (1988). Section 107 lists four factors to be considered in identifymg a fair use:

(1) the purpose and character of the use, including whether such use is of a commercial nature or is for nonprofit educational purposes; (2) the nature of the copyrighted work; (3) the amount and substantiality of the portion used in relation to the copyrighted work as a whole; and (4) the effect of the use upon the potential inarket for or value of the copyrighted work.

119. See, e.g., Sony Corp. of Am. v. Universal City Studios, Inc., 464 U.S. 417, $450-51$ (1984) (applying a narket test in a fair use case). For a discussion of the market test for infringement, see infra text accompanying notes 126-37.

120. For a clear application of the four-factor fair use test, sæe Harper \& Row, Publishers, Inc. v. Nation Enters., 471 U.S. 539 (1985) (finding no fair use where defendant published excerpts from President Ford's theretofore unrcleased inemoirs).

121. 434 F. Supp. 217 (D.N.J. 1977).

122. Id. at 221 .

123. Id. at 223-24. The court noted that had this been a replacing use (for example, providing cites directly to the New York Times), the defendants' index would have infringed, because the 
purchase the Times Index - the court found no harm to the plaintiff, and found the defendants' index noninfringing. ${ }^{124}$

Although nonrepiacing, enhancing works nay often be found noninfringing under a fair use analysis, fair use cannot consistently protect these works. The courts traditionally have not applied the fair use exception to commercial works; rather, they have limited the doctrine's scope to noncommercial researcli and educational works. "[E]very commercial use of copyrighted material is presumptively an unfair exploitation of the inonopoly privilege that belongs to the owner of the copyriglit . . ."125 Since many nonreplacing, enhancing works are commercial (particularly works of technological improvement), fair use doctrine may fail to protect many deserving, societally beneficial works that do not harm original authors. Therefore, rather than expanding the fair use doctrine to elnbrace commercial, nonreplacing, enhancing works, it is better to recognize nonreplacing, enhancing works explicitly and deem them noninfringing under a component works doctrine. This would avoid distorting traditional fair use doctrine, and allow courts to analyze nonreplacing, enhancing works under a better suited test.

\section{E. The Market Test for Infringement: A Promising Approach}

Courts and commentators have increasingly recognized the market test for infringement. ${ }^{126}$ The market test is used in place of or in addition to the substantial similarity test. The market test focuses on the allegedly infringing work's economic effect upon the autlior of the original work. ${ }^{127}$ If the subsequent work generates a significant demand that causes economic harm to the original author by replacing his work, then the subsequent work is deemed infringing. Copyright law employs the market test to determine infringement of various rights such as infringement of the riglit to display one's works ${ }^{128}$ and to perfornn one's

defendants" work would be "in direct coinpetition with the Times Index." Id. at 222. In other words, the new index could have stood on its own, and sales of the defendants' index would have hurt sales of the plaintiff's index.

124. Id. at 224 .

125. Sony Corp. of Am. v. Universal City Studios, Inc., 464 U.S. 417, 451 (1984).

126. See, eg., Goldstein, supra note 14, at 217, 232-33; Nimmer \& Kranthaus, supra note 14, at 37-39; Pilarski, supra note 108, at 351-52; Note, supra note 34 , at 1526-28 (some courts have identified derivative works by examining impact on market for original work); Note, supra note 5, at 462-64 (proposing an econoumic test for determining infringement); Comment, Does Form Follow Function? The Idea/Expression Dichotomy in Copyright Protection of Computer Software, 35 UCLA L. Rev. 723, 776-77 (1988) (authored by Peter G. Spivack) (proposing a market test in the remedy stage of infringement determination). But cf. Ladd, The Harm of the Concept of Harm in Copyright, 30 J. COPYRIGHT Soc'Y 421 (1983) (basing copyright protection on a showing of economic harm will cause authors to forego producing risky works).

127. Note, supra note 34 , at 1527 .

128. Cf. H.R. REP. No. 94-1476, supra note 13, at 80 (Congress forbade display of copyrighted 
works, ${ }^{129}$ as well as to determine fair use. ${ }^{130}$ Here, however, we will focus on the market test for infringement with respect to derivative works. ${ }^{131}$

In West Publishing Co. v. Mead Data Central, Inc., ${ }^{132}$ the court found infringement by using a market test. ${ }^{133}$ West publishes legal case reporters containing cases in a certain order, consecutively pagenumbered. The defendant markets LEXIS, an on-line legal computer database. LEXIS had already provided its subscribers witls each case's starting page number in the West reporter, and then it introduced a system called the LEXIS Star Pagination Feature. This systein allowed LEXIS users to obtain the exact West reporter page number for every LEXIS page of the case. Applying the market test, the court found Star Pagination infringing, since it replaced West's reporters:

With [defendant]'s star pagination, consumers would no longer need to purchase West's reporters to get every aspect of West's arrangement.... [Thus] the LEXIS star pagination feature would adversely affect West's market position. "[A] use that supplants any part of the normal market for a copyrighted work would ordinarily be considered an infringeinent." 134

Where the subsequent work eliminates the need for the original work, there is infringement, since the original author's incentive is destroyed. Thus, since copyright law seeks to promote authors' incentives, the inarket test achieves the proper result. LEXIS was allowed to continue using West's first-page numbers because, in contrast to Star Pagination, they do not allow a researcher to avoid using West's reporter entirely. In other words, they are a noureplacing use; they do not liarm the original author's incentive.

A reexamination of Vault Corp. v. Quaid Software, Ltd. ${ }^{135}$ also deinonstrates the advantage of the market test. Recall that under the sub-

work "in such a way that the copyright owner's market for reproduction and distribution of copies would be affected."), reprinted in 1976 U.S. CODE CONG. \& ADMIN. NEwS 5659, 5694.

129. See Teleprompter Corp. v. Columbia Broadcasting Sys., Inc., 415 U.S. 394, 410-13 (1974) (analyzing the market effects of reception and retransmission of certain broadcast signals, and determining whether they amount to "performance" and thus infringement).

130. See Sony Corp. of Am. v. Universal City Studios, Inc., 464 U.S. 417 (1984) (both majority and dissent applying market test to assess economic harm from VCR manufacture and sales). In the first Umited States fair use case, Folsom v. Marsh, 9 F. Cas. 342, 344-45 (C.C.D. Mass. 1841) (No. $4,901)$, Justice Story examined the market effects of the plaintiff's work, denouncing uses that "supersede the use of the original." Id. at 345.

131. See generally Goldstein, supra note 14, at 217 (The right to prepare derivative works begins when "the contribution of independent expression ... creates a new work for a different market.").

132. 799 F.2d 1219 (8th Cir. 1986).

133. See id. at 1227-28.

134. Id. at 1228 (quoting S. REP. No. 473, 94th Cong., 1st Sess, 65 (1975)).

135. 847 F.2d 255 (5th Cir. 1988). 
stantial similarity test, the court found that the defendant's unlocking prograin did not infringe the plaintiff's locking program. ${ }^{136}$ Under the market test, the defendant's unlocking program would reduce any demand for the plaintiff's locking program; the unlocking program would thereby constitute an infringing work. The market test therefore protects the original author's mcentive, restoring the constitutional balance between promoting new works and promoting public access to knowledge. As Professor Goldstein asserted: "More explicit and systematic attention to the economics of copyright's incentive system will produce better legislative and judicial decisions on derivative rights and derivative works."137

\section{F. Special Protection for Nonreplacing, Enhancing Computer Program Works}

In 1976, Congress created the National Commission On New Technological Uses of Copyright (CONTU), to study the use of copyright in conjunction with coinputers and to recommend appropriate changes in copyright law. In 1978, CONTU produced its Fimal Report, ${ }^{138}$ which, with one mimor modification, ${ }^{139}$ Congress enacted into law as section 117 of the 1976 Copyright Act. Seetion 117 states that

it is not an infringement for the owner of a copy of a computer program to make or authorize the making of another copy or adaptation of that computer program provided:

(1) that such new a [sic] copy or adaptation is created as an essential step in the utilization of the computer program in conjunction with a machine and that it is used in no other manner . . . ${ }^{140}$

This section deals exclusively with coinputer programs and estabhishes a special infringement exception. Arguably, section 117 might protect nonreplacing, enhancing computer programs. Under section 117, although one cannot inake a copy or an adaptation of a book or a movie, one can inake an adaptation or copy of a coinputer program. This might allow computer program coinponent works. Imagine, for example, a prograin that checks for spelling errors. The spelling program is

136. See supra text accompanying notes 65-67.

137. Goldstein, supra note 14 , at 252 . The market test, while a useful doctrine, alone would not suffice. A work that completely copied a prior work could still pass the market test if its effect on the original work was minor. Yet it would not add anything to the public wealth of knowledge, as required by coinponent works doctrine.

138. National COMm'N ON NEW Technological Uses of COPYRighted Works, Final REPORT (1979).

139. CONTU recommended that the section 117 rights apply to the "rightful possessor" of the computer program. Id. at 12. Congress changed this to "owner." See 17 U.S.C. $\$ 117$ (1988).

140. 17 U.S.C. $\$ 117$ (1988). Note that the last phrase "used in no other manner" is to protect the interests of the original copyright lolder, and means the adapter is forbidden from selling or otherwise transferring the adaptation. See infra text aecompanying note 150. 
designed to combine with a word processing program to produce an adapted word processing program. Since adaptations of coinputer programs are permitted, there is no infringement and the component work is allowed. ${ }^{141}$ Nintendo of America, Inc. v. Lewis Galoob Toys, Inc. ${ }^{142}$ illustrates the issue of coinponent works under section 117. Nintendo makes video game cartridges to be inserted into the Nintendo coinputer. Galoob invented a computer chip that the home user can attach to the Nintendo cartridge before inserting the cartridge into the coinputer. The computer chip, called the "Game Gerie," allows the video game user to provide his video game character with more hives or greater abilities, such as being able to jump higher or inove faster. The Gaine Geine is clearly a nonreplacing, enhancing work: it is useless by itself and is dependent on the Nintendo cartridge. To use the Game Gemie, the user must purchase a Nintendo cartridge and the Nintendo computer.

A court could have ruled that when one combines the Game Genie and the Nintendo cartridge, an adaptation is created. Even though it is unlawful to create an adaptation or derivative of someone else's work, ${ }^{143}$ the Game Genie would fall under the section 117 exception for computer program adaptations.

Nimtendo argued that Game Genie did not fall under section 117, because that section only allows adaptations essential to the use of the program. Since the game worked without the Game Genie, the Game Genie could not be "essential." This reading is too narrow, however. The CONTU Final Report, enacted almost verbatim and without debate, should be considered persuasive in interpreting section $117 .^{144}$ The Final Report states that features not present at the time of purchase can none-

141. A simple example explains why a person can copy a computer program (that she already owns) for her personal use, but can never copy a book, even for personal use. Unlike a book, a computer program can easily be destroyed or accidentally erased. A backup copy therefore is essential to preserve access to the program. On the other hand, a book is a solid object. While a book too could become damaged or lost, the owner has far less ability to protect a computer program.

142. No. 90-15936 (9th Cir. Jan. 24, 1991) (1991 U.S. App. LEXIS 1160) (affirming grant of preliminary mjunction). Originally, Nmtendo sought a temporary restraining order against Galoob, and it was demied. Nintendo Denied in Court, N.Y. Times, June 12, 1990, § D, at 20, col. 5. On June 29, 1990, however, Nimtendo won a preliminary injunction. Nimtendo of Am., Inc. v. Lewis Galoob Toys, Inc., No. CV90-1586 (N.D. Cal. Jime 29, 1990); see also Motamedi, Galoob Loses Ruling on Video Game Device, San Francisco Chron., June 30, 1990, at B1.

This Cominent uses Nintendo to highlight certain copyright issues, and does not rely on the holdings in the court's unpublished opimion.

143. 17 U.S.C. \$ 106 (1988).

144. See, e.g., Apple Coinputer, Inc. v. Franklin Computer Corp., 714 F.2d 1240, 1252 (3d Cir. 1983) (Congress "wrote into the law the majority's recominendations almost vcrbatim."), cert. dismissed, 464 U.S. 1033 (1984); H.R. ReP. No. 1307, 96th Cong., 2d Sess., pt. 1, at 23, reprinted in 1980 U.S. CoDE CoNG. \& ADMIN. News 6460, 6482 (Section 117 "embodies the recommendations of [CONTU] with respect to clarifying the law of copyright of computer software."). 
theless be added to the purchased program. ${ }^{145}$ The term "essential" in the statute likely ineans essential to the buyer's utilization of the program. The buyer's desires should be the issue, and not the intention of the seller of the program. ${ }^{146}$

Indeed, courts have construed the computer program user's section 117 adaptation rights broadly: "[T] $]$ he weight of the inore recent cases and scholarly commentary is on the side of reading [section] 117 broadly, in conformity with the apparent intent of [CONTU]."147 Moreover, because ordinary purchasers lack coinputer expertise, they can purchase equipinent enabling thein to adapt their computer programs for their desired uses. ${ }^{148}$ Such equipinent for sale to nonexpert purchasers is called a third-party program. The Game Geme is such a third-party program since it provides the ability to make desired adaptations. ${ }^{149}$

Another potential limitation of section 117 is that it allows only personal use of adaptations, and not sale or transfer of the adaptation. ${ }^{150}$ Thus, a third party cannot sell the adaptation itself. It can only sell the "tools" to inake adaptations. This distinction is perfectly consistent with the proposed coinponent works doctrine. The adaptation itself is not a noureplacing, enhancing work, for the adaptation wonld be a coinplete program-like the word processing program adapted with a program that checks spelling. For example, the Game Geme and the Nintendo cartridge constitute an adaptation when they work together as an integrated coinputer game. The "tools," on the other hand, are dependent upon the original program and cannot be used without it. Thus, section 117 allows nonreplacing, enhancing works such as the Game Geme to be marketed separately.

The preceding discussion, however, only analyzes the potential pro-

145. National COMm'N ON NEW TEChNOLOGICAL USES OF COPYRIGHTED WORKS, supra note 138 , at $13-14$.

146. See, e.g., Vault Corp. v. Quaid Software, Ltd., 847 F.2d 255, 261 (5th Cir. 1988) ("Section 117(1) contains no language to suggest that the copy it permits must be employed for a use intended by the copyright owner, and, absent clear congressional guidance to the contrary, we refuse to read such limiting language into this exception.").

147. Foresight Resources Corp. v. Pfortmiller, 719 F. Supp. 1006, 1009-10 (D. Kan. 1989); see also RAV Communications v. Phillipp Bros., 1987-1988 Copyright L. Dec. (CCH) If 26,263, at 21,782 (S.D.N.Y. 1988) (noting that section 117 should receive "a broader reading where the owner of a copy of a computer program adapts it for his own internal use").

148. Many computer program owners are not computer programmers and "lack the skills and equipınent necessary to make adaptations to existing computer programs.' " Foresight, $719 \mathrm{~F}$. Supp. at 1010 (quoting Stern, Section 117 of the Copyright Act: Charter of Software Users' Rights or an Illusory Promise?, 7 W. NEW ENG. L. Rev. 459, 468 (1985)).

149. A related issue is whether the user can make an adaptation to the computer code only, or whether she can make an adaptation to the output (i.e., the screen display). The Foresight court held that, consistent with CONTU's intent, the program owner conld employ third parties' programs to add features to the program that change the screen display. $719 \mathrm{~F}$. Supp. at 1009.

150. See supra text accompanying note 140 (reprinting statute). 
tection section 117 might provide to nonreplacing, enhancing works. The courts have not as yet ruled on whether section 117 will apply as suggested here. In addition, even if section 117 were interpreted to protect nonreplacing, enhancing works, it protects such works only in the computer context. Thus, although existing law may protect soine coinputer program component works, it is hazardous to rely on speculation as to what courts might do. Moreover, it would be preferable to provide protection to nonreplacing, enhancing works on a broader spectrum, rather than relying on this narrow exception. This Comment will now address directly why separate recognition of component works is necessary.

\section{III}

Proposal: The Component Works Doctrine and the MARKET TEST FOR INFRINGEMENT

Part II demonstrated that the existing copyright doctrines do not adequately protect nonreplacing, enhancing works, even though the goals underlying copyright law call for protection of such works. Part III proposes a doctrine by which courts can provide this needed protection. First, this Part will set out the four-part definition of component works. Then, it will examine how the market test for infringement can determine substantial harm. Finally, this Part will argue that recognizing component works will best serve the purposes behind copyright law.

\section{A. Component Works Are Defined by Four Characteristics}

The fundamental purpose of copyright law is to further two coinpeting goals: to protect authors' incentives, and to expand the public's realm of knowledge. Component works are justified in hight of this dichotomy. Component works must (1) depend on the original work, (2) add value to the orignial, but (3) not replace the orignial work, (4) nor cause substantial economic harm to the original author, as measured by the market test for infringement.

\section{Component Works Are Dependent}

A defining feature of a component work is that it is designed to go with someone else's original work. It is dependent upon the original work, and cannot function on its own. As we have seen, an example is a computer chip made for insertion into a particular video game, to speed up the action. ${ }^{151}$ Another example is an answer sheet designed to go

151. For example, the computer chip in Midway Manufacturing Co. v. Arctic International, Inc., 547 F. Supp. 999 (N.D. Ill. 1982), aff'd, 704 F.2d 1009 (7th Cir.), cert denied, 464 U.S. 823 (1983), could have been deemed a component work. 
with someone else's publislied test questions. ${ }^{152}$

\section{Component Works Add to the Public Wealth of Knowledge}

Further, a component work must not be an exact copy of some part of the original work. Nor, in the case of an audiovisual work, may a component work act to create an identical audiovisual image. It mnst add something. ${ }^{153}$ It must enhance the original work's utility. This ensures some advancement of the public knowledge-the underpinning upon which the concept of component works rests.

Professor Raymond Nimmer and Patricia Krautlians distinguish between infringing copies and infringing derivatives. ${ }^{154}$ They consider the twin opposing objectives of copyriglit law, and conclude that "the copyriglit loolder's interest is offset by policies to maintain frec use and access to aspects of a work that are or become central to the field of technology."155 Yet the copyright lolder's interest is only offset if there is some public benefit from the infringing use. In other words, the second party must add something to the original work, ${ }^{156}$ which is a "valueadded use."157 Merely to copy, on the other hand, does not add anything to the public knowledge. ${ }^{158}$ Thus, "[t]lie second party's interests do not justify comprehensive, hteral copying, but rather productive or developmental use."159 A derivative work, then, is superior to a copy, or pirated, work. Unlike the commercial pirate, the second developer contributes to the new product. More significantly, a component work is better than a

152. See Harcourt, Brace \& World, Inc. v. Graphic Controls Corp., 329 F. Supp. 517 (S.D.N.Y. 1971) (psychological test answer sheets with blank spaces for the answers could have been deemed component works).

153. For example, consider a word processing program that includes a program to check spelling. Another author cannot simply duplicate that program and call it a component work on the grounds that it is dependent on the word processing program, for it would not add anything. A better spelling program could be sold separately as a component work, however. See Nimmer \& Krauthaus, supra note 14, at 29-30 (discussing the concept of "value-added use").

154. Id. at 38-39. More precisely, Nimmer and Krauthaus refer to "would-be" infringing derivatives (i.e., works that would infringe but for this "value-added" idea).

155. Id. at 38 .

156. Id. at 16; see also Chafee, supra note 53, at 514 ("There comes a point where the use of material is so close as not to give the public anything really new. At that point, the ideal of encouraging independent crcation ceases to operate.").

157. Nimmer \& Krauthaus, supra note 14, at 13. Copyright law protects value-added use im other contexts, such as fair use. See, e.g., Rosemont Enters. v. Random House, Inc., 366 F.2d 303, 307 (2d Cir. 1966) (requiring a public benefit from the allegedly infringing work before deeming it a fair use), cert denied, 385 U.S. 1009 (1967); see also Sony Corp. of Am. v. Universal City Studios, Inc., 464 U.S. 417, 478 (1984) (Blackmun, J., dissenting) (requiring a fair use to be a "productive" one).

158. Nimmer \& Krauthaus, supra note 14, at 21, 29. "Value-added use is not equivalent to piracy. The pirate merely dupticates the program for commercial gain. ... In contrast, the person who creatively enhances the original or uses aspects to develop a new product participates . . . in a comprehensive approach to promoting innovation." Id. at 29.

159. Id. at 39. 
copy or a derivative work. In a value-added use, a subsequent developer adds her own innovation to prior work. This, by definition, is exactly what happens in a component work. Moreover, unlike mere value-added derivative use, the nonreplacing use will not render the original author's work obsolete. Thus, if one accepts the premise that value-added works should be deemed noninfringing, regardless of whether the new work replaces the original, a component work is even more acceptable. A component work has all the societal benefits of a value-added work, without the harm to original authors that is likely with ordinary replacing, value-added works.

\section{Component Works Are Nonreplacing}

Another central featnre of a component work is that it does not replace or destroy the original work. Simply stated, such works do not eliminate the public's need for the original work. One example of a replacing work is a "clone" computer program-a cheaper, unauthorized version of an existing program, written for a different computer operating systein. ${ }^{160}$ This program, though for a different systein, could ultimately cut into the market share of the original program: if the public begins to buy the new system to use the new program, sales of the old system will decrease, as will the demand for its programs. This is a replacing use. Simce component works are ultimately justified on the delicate balance between the public interest in knowledge and the minimization of economic harm to original authors, component works are defined to exclude replacing uses. ${ }^{161}$ In sum, since component works are dependent on the original work and are nonreplacing, they do not typically harn the original authors' mcentives, allowing copyright law to pursue its other goal: to increase the realm of public knowledge. ${ }^{162}$

160. For an example of a derivative program that should not be considered an allowable component work, see Q-Co Industries, Inc. v. Hoffman, 625 F. Supp. 608 (S.D.N.Y. 1985). In Q-Co, the defendant developed a teleprompter program for IBM's personal computer based on the plaintiff's teleprompter program for Atari's computer. This is not a component work, since the defendant's program eliminated the need for the plaintiff's program, and could operate independently.

161. Note that I do not use "replacing" hiterally. If the purported component is really the substantial part of the original whole, then it is deemed to "replace" the original work. For instance, where a second author makes an infringing computer and alleges that the computer is the "component" for the original computer's software, it is clear that the component is really the software, and the computer is the substantial part of the worl. See Apple Computer, Inc. v. Franklin Computer Corp., 714 F.2d 1240 (3d Cir. 1983), cert. dismissed, 464 U.S. 1033 (1984). Another example is a song. Both the music and the lyrics are substantial parts, so one could not market new words to a song as a component work. Or, consider a supplement for a case reporter. One could not market competing supplements and call them component works, for the supplement really stands on its own. One does not really need the original reporter to use the supplement.

162. Courts have deeided cases by following exphicitly the constitutional balance. For instance, the Ninth Circuit permitted a defendant to make a subsequent work, on grounds that restricting him "would effeet the very opposite of the [Copyright Act]'s purpose." Warner Bros. Pictures, Inc. v. 


\section{Component Works Do Not Cause Substantial Harm to Original Authors}

In general, the approach to component works discussed above will benefit both original authors and component works producers. ${ }^{163}$ Nonetheless, the potential for harm to the original author, both in the component works market and in the original market, remains. In the component works market, the original author may be harmed because without a component works doctrine, he might have the exclusive right to a "helper" program, such as a program that checks spelling to go with his word processing program. Thus the existence of the new program may hinder sales of his own "helper" prograin. ${ }^{164}$

Yet the gaim from enhanced sales of his word processing program may overcome the potential loss in sales of his "helper" program. Or if his own "helper" program is better, sales of the new program may not be significant. Moreover, the original author could incorporate his own "helper" program into his word processing prograin, so that anyone buying the word processing program would already have a "helper" program. ${ }^{165}$ Additionally, the component works doctrine also benefits the

Columbia Broadcasting Sys., Inc., 216 F.2d 945, 950 (9th Cir. 1954), cert. denied, 348 U.S. 971 (1955).

163. A potential criticisin of the proposed component works doctrine is that since the component work by definition does not harm the original author, the original author would not need to enjoin its distribution. If this were true, no separate exception would be necessary. However, without the proposed doctrine, the original author could extort a license agreenent from the component author, even if the component work benefited the original author. Given the disparate and mconsistent treatment component works have traditionally received, the threat of a lawsuit is very real, as it might succeed, particularly in the technology field. Since new works require lead time and pecuniary investment, would-be authors of improvements will be reluctant to develop component works if they can rely ouly upon the goodwill of the original author not to seck an injunction. Moreover, since the time and inoney will have been invested already, and the coinponent author would need to market the new product to recoup the imvestinent, the original author will have additional leverage to force an unfair licensing agreement upon developers.

Alternatively, if the law required component authors to acquire a license before marketing their work, then the lack of harm to the original author would become irrelevant, for the original authors would already have extorted a heense. Indeed, to force authors of improvenents first to acquire licenses, the original authors would have to sue all those who do not, to make the threat credible. Aecordingly, a component works exception is necessary, because even harmless works would engender litigation.

Additionally, not all component works are beneficial to the original owners. Some works may have a neutral or slightly negative effect. In such cases, the problems delineated above will becoine more acute, and the need for a component works exception will increase correspondingly. In other words, the fact that component works do not substantially harm original authors will preclude neither the possibility of litigation, nor the resulting need for a separate component works exception.

164. But see New York Timies Co. v. Roxbury Data Interface, Inc., 434 F. Supp. 217, 224 (D.N.J. 1977) (rejecting the argument that since the plaintiff could have come up with the work on its own, there exists some harm to the plaintiff).

165. Note that if component works were disallowed, the original author, having established an industry standard, could suddenly become the exclusive producer of components compatible with the imdustry standard. Menell, supra note 106, at 1344 ("By tying a product standard to 
original author (as well as the component work author) by clarifying the nebulous "derivative works" test, thereby reducing uncertainty costs. ${ }^{166}$

In any event, protection of the original author's work should probably not extend to the component works market if the component work has no substantially harmful effect on the original product. In that situation, his incentive to create is not impaired. Moreover, giving him monopoly power is likely to discourage further development.

On the other hand, component works that substantially harm the original author's product should be prohibited. ${ }^{167}$ If the component work causes substantial economic harm to the original author, the new program should be prohibited as infringing. ${ }^{168}$ But it should be noted that even a mildly negative effect on the original author is acceptable. The courts have been clear in emphasizing the public imterest goal of copyright law, even at the expense of authors' mcentives. That is, "reward to the owner [is] a secondary consideration."169 Indeed, the Supreme Court has asserted that " " $[\mathrm{t}]$ he sole interest of the United States and the primary object in conferring the monopoly he in the general benefits derived by the public from the labors of authors." "170 Accordingly, as the public interest goal is the primary one, a shightly negative effect on authors' incentives is justified, if not common.

If the developer of the original [product] spent millions of dollars to create and market it, should an enhancer then be permitted to deprive the developer of soine of the fruits of his or her labor by marketing a coinpeting, possibly superior product that builds upon the original developer's own substantial imvestment? However our sense of justice might lead us to protect the original developer's investment, the open coinpetition

complementary products, a monopolist can effectively discourage other firms from attempting to improve such complementary products .... This can delay socially valuable innovations ....").

166. See Hazen, supra note 10, at 128-29. A component works doctrine also would clarify the parties' rights and avoid needless harassment or threat of hitigation. See Durham Indus., Inc. v. Tomy Corp., 630 F.2d 905, 910-11 (2d Cir. 1980) (discussing threat of harassment arising in confusion over scope of derivative rights and licensing). This would also clarify the licensing situation. Licensees would know not to rely upon exclusive agreements to produce what would be a component work. Yet because the plaintiff would still have protection under the trademark laws, see infra note 179, a component works author could not use the plaintiff's logo, for instance. Thus, the plaintiff still would have something profitable to license.

167. "Substantial harm" is defined here as harm to the original autlor greater than the mildly negative effects allowed by the Supreme Court in its effort to encourage innovation.

168. See infra text accompanying notes 176-79.

169. United States v. Paramount Pictures, Inc., 334 U.S. 131, 158 (1948).

170. Id. (quoting Fox Film Corp. v. Doyal, 286 U.S. 123, 127 (1947)); see also Rosemont Enters. v. Random House, Inc., 366 F.2d 303, 307 (2d Cir. 1966) (To serve "the constitutional purpose in granting copyright protection in the first instance, to wit, "To Promote the Progress of Science and the Useful Arts[,]" U.S. CoNST. art $1 \S 8$," courts "'must occasionally subordinate the copyright holder's interest in a maximum financial return to the greater public interest in the development of art, science and industry.' " (citation omitted)) (quoting Berlin v. E.C. Publications, Inc., 329 F.2d 541, 544 (2d Cir. 1964)), cert. denied, 385 U.S. 1009 (1967). 
described in the question has been commonplace .... ${ }^{171}$

Since, by definition, coinponent works are nonreplacing and are dependent on the original work, they usually will not cause economic harm to the original author. Occasionally, however, a component work may cause economic harm to the original author. ${ }^{172}$ In each component works case, the owner of a copyright to the original work should be permitted to defeat the presumption of noninfringement with a showing of substantial harm. The best way to do this, under existing law, would be to einploy the market test for infringeinent, which contains a built-m harm inquiry.

\section{a. Substantial Economic Harm Can Be Measured by the Market Test for Infringement}

By applying the market test in conjunction with the definition of coinponent works, courts will be able to meet the goals of the copyright law while protecting original authors' imcentives. ${ }^{173}$ The market test is desirable since it already focuses on many factors einphasized in the defimition of coinponent works. First, the inarket test focuses on the subsequent work's replacement of the original work. Second, the market test considers whether the original author suffers economic harm. In Vault Corp. v. Quaid Software, Ltd., ${ }^{174}$ for example, the harm to the locking program's author would mandate a finding of infringeinent. Third, one commentator defines derivatives as works that "serve markets that differ froin the inarket in which the original was first introduced."175 Even under this version of the inarket test, component works are noninfringing. Coinponent works do not serve different markets, since by definition they function only when used with the original work. Component works expand the market share, but within the inarket carved out by the original.

By any criterion, therefore, the inarket test for infringement permits coinponent works to stand, even without recognizing them as a separate category. Although under existing law courts inay imphicitly recognize component works and find thein noninfringing under a inarket test, it would be better to recognize them exphicitly. Exphicit recogintion would help clarify authors' expectations. Further, inany courts have not employed tlie market test. But explicit recoginition of coinponent works

171. Gemignani, supra note 5 , at 409 (footnote omitted) (arguing that this "open competition" should be extended to the software context).

172. See infra text accompanying notes 176-79.

173. The market test alone would not suffice. A work that completely copied a prior work could still pass the market test if its effect on the original work was minor. Yet it would not add anything to the public wealth of knowledge, as required by component works doctrine.

174. 847 F.2d 255 (5th Cir. 1988); see supra text accompanying notes 65-67.

175. Goldstein, supra note 14 , at 217. 
would encourage or require use of the coinpatible inarket test. Finally, exphcit recognition will lead to inore well-reasoned, predictable opinions.

\section{b. An Example of How the Market Test Will Measure Substantial Harm}

By applying the component works doctrine with the inarket test, even when the original author has proven a negative inipact he must make a showing of substantial harm to overcome society's interest in the dissemination of knowledge. ${ }^{176}$ An example of substantial harm is Hubco Data Products Corp. v. Management Assistance, Inc. ${ }^{177}$ Management Assistance, Inc. (MAI) marketed a series of personal coinputers. Each model had the same memory capability, but the less expensive models contained chips that limited the available memory. Hubco inarketed a software program that could neutralize the memory-limiting chip, allowing the less expensive model to realize the same meinory as the top-of-the-line model. ${ }^{178}$ This component work computer program might enhance sales of MAI's computer. At the same tinie, it would decrease sales of MAI's more expensive model. If the decrease in sales of the expensive model substantially outweighed the increase in sales of the cheaper model, then the component work would infringe.

As noted previously, however, if the component work is truly dependent, the economic harm usually will be insubstantial. Consider an author who writes a different last chapter for another author's wellknown mystery novel. Under the component works doctrine, the subsequent author can only market that new chapter, and not the rest of the book. Thus, the public will need the original to inake any sense out of the component work, and sales of the original work should not suffer. ${ }^{179}$ To allow component works would save many previously banned works that are not harmful. Thus, to deem coinponent works noninfringing would not create an empty category. Indeed, recogintion of the compo-

176. See Note, supra note 34 , at 1551 (applying a fair use/harm exception to derivative works).

177. 219 U.S.P.Q. (BNA) 450 (D. Idaho 1983).

178. Id. at 452. The court issued a preliminary mjunction restraining Hubco from using its method of neutralizing the memory-limiting chip. Id. at 457-58.

179. Note, however, that status as a component work does not exempt the work from the trademark, unfair competition, patent, and trade secret laws. For instance, if this subsequent author pretended the new last chapter was in fact written by the original author, the subsequent author would be hiable under section 43 of the Lanham Act for "passing off." See 60 Stat. 427, 441 (1946) (codified at 15 U.S.C. § 1125(a)). Consider New York Tünes Co. v. Roxbury Data Interface, Inc., 434 F. Supp. 217 (D.N.J. 1977), discussed at supra text accompanying notes 121-24. The plaintiff published the New York Times Index. The defendant published an index to the plaintiff's index, called the Personal Name Index to 'The New York Times Index.' To avoid liability for "passing off," separate from any copyright hability, the defendant's index included a disclaimer to show it did not come from the plaintiff: "An independent work not published or approved by The New York Times." Id. at 226 (emphasis ormitted). Thus, without the disclaimer, this component work inight have been subject to Lanham Act liability. 
nent works doctrine would protect component works by presuming noninfringement. This presumption may be rebutted, however, if the original author can, prove that the component work substantially harms the profitability of the original work.

In sum, the component works doctrine has four parts. To be a component work, the work must be dependent, nonreplacing, add something to the public knowledge, and avoid harming the original author's incentives, as measured by the market test.

\section{B. Illustrations: Why the Component Works Doctrine Furthers Copyright Law's Essential Goals}

As this Cominent has emphasized, copyright law is designed to balance the coinpeting goals of promoting authors' mcentives and protecting the public's access to new works. ${ }^{180}$ Thus, if $A$ develops a product that is subsequently copied and sold by $B, B$ 's work is deemed an infringement. Clearly, if the author's work is coinpeting for sales with the infringing copy, the author suffers economic harm with every copy the infringer sells. ${ }^{181}$ As a result, sales of the unautliorized copy may be enjoined, ${ }^{182}$ even though an imjunction will foreclose public access to $B$ 's work. In such a case, the harm to $A$ 's incentive (his profit motive) outweighs the pubhic's imterest in access to $B$ 's work.

On the other hand, if $B$ produces a work that has either a neutral or positive effect on the sales of $A$ 's product, distribution of $B$ 's work should be permitted. $A$ 's imcentive to create has not diminislied, and the public store of knowledge has imcreased. In otlier words, the two goals become compatible in coinponent works. As the Supreme Court has stated:

The purpose of copyright is to create incentives for creative effort. . .

But a use that has no demonstrable effect upon the potential market for, or the value of, the copyrighted work need not be prohibited in order to protect the author's incentive to create. The prohibition of such ... uses would inerely inhibit access to ideas without any countervailing benefit. $^{183}$

The component works doctrine promotes both goals of copyright

180. See supra text accompanying notes 8-11.

181. Indeed, the infringer, with little or no development costs, may be able to offer the work at a drastically lower price, reducing sales of the original product even further.

182. 17 U.S.C. $\$ 502(a)$ (1988) ("Any court having jurisdiction of a civil action arising under this title may ... grant temporary and final injunctions on such terms as it may deem reasonable to prevent or restrain infringement of a copyright.").

183. Sony Corp. of Am. v. Universal City Studios, Inc., 464 U.S. 417, $450-51$ (1984). Although the Court applied this reasoning to noncommercial activity, that fact does not preclude its applicability to commercial activity. The only difference betwecn commercial and noncommercial activity in this context is that in the former case, the developer of the component work experiences financial gain. This difference is irrelevant to the imquiry into whether the market for the original work suffered harm. 
law on precisely this rationale. For example, suppose $A$ creates a word processing program, WriteWell. $B$ then develops a spelling checker, Spell'R, that is based on and designed to be used with WriteWell. Spell'R is a component work. First, Spell'R is dependent upon WriteWell, and cannot function on its own, since buying Spell'R will not allow the purchaser to do word processing. Second, Spell'R enhances the original word processing program. Using both products, the consumer can create documents and check the spelling. Spell'R does not replace WriteWell or make it obsolete, and a sale of Spell'R does not prevent a sale of WriteWell. On the contrary, Spell'R makes WriteWell more marketable, since the combined programs will result in a more effective word processing system. Sales of WriteWell would likely mcrease, decreasing the potential for economic harm to WriteWell's author. WriteWell's author's imcentive to create still remains, and the public ability to do word processing has expanded. Thus, the conjunction of the original and component works helps meet both of copyright law's goals.

Additionally, the idea-expression distinction supports component works. It has long been settled that an idea, im contrast to expression of an idea, is not copyrightable. ${ }^{184}$ In other words, everyone is free to copy an idea. With Teddy Ruxpin, for mstance, the defendant merely copied and capitalized on the idea of a talking bear-he did not attempt to market his own competing expression of the bear. Had the defendant sold a talking bear to go with the tapes, he would have been copying the plaintiff's expression. Had he sold a bear, however, his work would no longer have been dependent upon the original, and would no longer have been a component work. Audiovisual component works thus do not infringe.

Recall Midway Manufacturing Co. v. Artic International, Inc., ${ }^{185}$ where the defendant marketed a computer chip to be placed inside the plaintiff's video game. The expression is the audiovisual display of the video game. A computer chip, by itself, cannot produce an audiovisual display at all. It thus is not expression. The computer chip copies the same idea, of course, but that is permissible. Simce component works cannot copy the substantial part of the original, and cannot produce a display without the original work, the original work itself must always produce the audiovisual display. Ouly the idea has been copied. The expression-the display-has not. In addition, as the defendant's work copies the plaintiff's idea but not the plaintiff's expression, the compo-

184. See supra notes 13-18 and accompanying text; see, eg., Whelan Assocs. v. Jaslow Dental Lab., Inc., 797 F.2d 1222, 1234-35 (3d Cir. 1986) (providing a brief history of the dichotomy in copyright law between idea and expression), cert. denied, 479 U.S. 1031 (1987).

185. 547 F. Supp. 999 (N.D. Ill. 1982) (order granting prelimmary injunction), aff'd, 704 F.2d 1009 (7th Cir.), cert. denied, 464 U.S. 823 (1983); see supra text accompanying notes 61-63; see also infra text accompanying notes 198-203. 
nent work is insulated from the look-and-feel doctrine. The look-andfeel doctrine, while it attempts to protect the feel of a work, claims to respect the rule that ideas are not protected.

Interpreting the component work as a copy of the idea would pose little difficulty. Indeed, the malleability of the line between idea and expression is what inakes the issue so complex. ${ }^{186}$ As Judge Learned Hand observed: "Obviously, no principle can be stated as to when an imitator has gone beyond copying the 'idea,' and has borrowed its 'expression.' Decisions must therefore mevitably be ad hoc."187 Courts are free to define component works as copying only the idea of the original, the original itself producing the expression-the audiovisual display. As the Ninth Circuit observed:

The critical distinction between "idea" and "expression" is difficult to draw. . . . At lcast in close cases, one may suspect, the classification the court selects may simply state the result reached rather than the reason for it. ... The guiding consideration in drawing the line is the preservation of the balance between competition and protection reflected in the patent and copyright laws. ${ }^{188}$

Thus, not only are the courts free to view component works as copymg only ideas, this result is mandated by the rationale behind the determination: to minimize larm to authors' incentive while maximizing the public's interest in knowledge. Since the component work is justified in higlt of this balance between competition and protection, "idea" must be defined to mclude component works. Accordingly, component works wonld be decmed noninfringing under all tests.

Indeed, recognizing component works would not constitute a drastic departure from copyright law, but a step in the right directionimphicitly approved by copyright decisions. In the landinark case of Lotus Development Corp. v. Paperback Software International, ${ }^{189}$ Judge Keeton recognized the possibility of component works. In this case Lotus sued because Paperback's new spreadsheet program resembled Lotus' best-selling Lotus 1-2-3 spreadsheet program. Lotus 1-2-3 dominates the spreadsheet market. ${ }^{190}$ In other words, people only knew one

186. One commentator aptly described the idea-expression distinction's elusiveness by quoting W.B. Yeats: "O body swayed to music, $O$ brightening glance, / How can we know the dancer from the dance?" Comment, supra note 45, at 293 n.81 (quoting W. B. YEATS, Among School Children, in W.B. Yeats: The PoEMS 217 (R. Finneran ed. 1983)).

187. Peter Pan Fabrics, Inc. v. Martin Weiner Corp., 274 F.2d 487, 489 (2d Cir. 1960); see Nimmer \& Krauthaus, supra note 14, at 41 (observing that in audiovisual cases the courts manipulate the idea-expression distinction in order to achieve the proper balance between the interests of original and snbsequent authors).

188. Herbert Rosenthal Jewelry Corp. v. Kalpakian, 446 F.2d 738, 742 (9th Cir. 1971) (citations omitted).

189. 740 F. Supp. 37 (D. Mass. 1990).

190. Id. at 78-79. Paperback's "industry standard" argument implied that Lotus 1-2-3 was 
way to use a spreadsheet-the Lotus 1-2-3 way. Thus, Paperback concluded, all new spreadsheet programs must resemble Lotus 1-2-3. Judge Keeton disagreed, finding Paperback's spreadsheet substantially similar and therefore infringing. Paperback, rather than copying, should have sought a license, or tried to sell its ideas to Lotus. ${ }^{191}$

Judge Keeton offered a third alternative, however: Paperback could have marketed a component work, or what he called an "add-in" program. ${ }^{192}$ He defined an add-in as "a program designed to be used in conjunction with another program." 193 It would not be "a stand-alone product that completely replaces" the plaimtiff's program, as did Paperback's spreadslieet. ${ }^{194}$ By way of example, Judge Keeton observed that "HAL is a program that is used in conjunction with 1-2-3-a user must have both HAL and 1-2-3-which allows a 1-2-3 user to enter coinmands in simple sentences . . . rather than by selectimg commands froin the menus." 195 This dependent, nonreplacing use exactly fits the proposed definition of component work. To use the component work, one must pnrchase Lotus 1-2-3; thus, the component work benefits the original author and his incentives to create.

Further, not only are component works noninfringing, Lotus Corporation actually encourages them. "To encourage the creation of add-im programs (which, in turn, make [Lotus] 1-2-3 a more attractive program to potential customers), Lotus has published . . . [d]eveloper [t]ools that help[] developers write add-in programs."196 In noting that these component works made Lotus 1-2-3 "a more attractive program to potential customers," 197 Keeton implicitly found that there was no substantial harm to the original author. Under the name "add-in" works,

analogous to the QWERTY typewriter. A QWERTY typewriter is one with the usual arrangement of keys. The name derives from the first six letters, from left to right, of the top letter line of a standard typewriter. All manufacturers must use this arrangement of keys (to which no one has a copyright). After all, even if a different order might be more efficient, why would anyone buy a typewriter with keys in a different order, forcing one to relearn how to type? This explains the lack of success of the more efficient Dvorak keyboard.

191. Id.

192. Id. at 78.

193. Id.

194. Id. at 79. Thus, each sale of an add-m program would require a purchase of Lotus 1-2-3 as well, while each sale of Paperback's complete spreadsheet program meant one less sale for Lotus.

195. Id. at 78. Note the similarity of the $H A L$ example to the WriteWell example employed at supra text following note 183.

196. Id. at 78-79. Apple Computer, Inc. also provides developer tools to outside developers, to encourage them to create component works for Apple's computers. McGeever, Appletalk Leans on Third Parties, INFo WoRLD, Mar. 11, 1985, at 20 ("Apple is relying completely on third-party developers to supply the hardware and software necessary.").

197. Lotus, 740 F. Supp. at 78-79. Recall that a component work that causes substantial economic harm to the original author will be disallowed, since authors' incentives will be at risk. See supra text accompanying notes $126-37 \& 164-72$. 
then, Judge Keeton has attached judicial imprimatur to the concept of component works.

Judicial recognition of component works would help courts reach well-reasoned decisions. Consider again the case of Midway Manufacturing Co. v. Artic International, Inc. ${ }^{198}$ The plaintiff manufactured the video gaine Galaxian. The defendant produced a computer chip to be placed in the console, speeding up the gaine. The chip was clearly a component work - it was dependent on the orignial work, and did not replace it. Even though the court determined that the plaintiff could not lose any sales as a result of the defendant's product, it still found the speed-up kit infringing. ${ }^{199}$

The court's real problem was its failure to recognize the component works issue. It merely examined the effect of the speed-up kit on the original work, and concluded that

Artic's speed-up kit modifies Midway's Galaxian game in such a way as to make it considerably more difficult, for the unskilled player im particular. It is very possible, if not likely, that that will discourage those individuals from playing Midway's video games and so reduce the overall demand for [Midway's] games. ${ }^{200}$

This conclusion is erroneous. Video games tend to lose popularity as more and more people master them or get used to them. ${ }^{201}$ Since the effect of the speed-up kit is to encourage players to try to re-master Galaxian, ${ }^{202}$ the coinponent work increases the demand for the game. Thus, the court should have concluded that the speed-up kit was not an infringement.

The result in Midway v. Artic could have been avoided if the court had employed the rationale behind the component works doctrine. The court should not have made its own determination of "harm."203 Rather, the plaintiff should have had the burden of showing substantial harm. With the test inore clearly delineated in advance, plamtiffs will

198. 547 F. Supp. 999 (N.D. Ill. 1982), aff'd, 704 F.2d 1009 (7th Cir.), cert. denied, 464 U.S. 823 (1983).

199. Id. at 1014.

200. Id.

201. “A [video] game's commercial popularity often terminates abruptly after a short period of time. The average game generally would lose its appeal within a year of being introduced on the market." Midway Mfg. Co. v. Dirkschneider, 543 F. Supp. 466, 473 (D. Neb. 1981); see also Nimmer \& Krauthaus, supra note 14, at 58.

202. See Midway Mfg. Co. v. Strohon, 564 F. Supp. 741, 744 (N.D. Ill. 1983).

203. Since Midway v. Artic involved a preliminary injunction, the harm analysis was conducted using the irreparable harm standard. Thus, perhaps it is unfair to criticize the court,for finding harm here, since "the burden on the plaintiff to show irreparable harm necessary to support a preliminary injunction is very light." Midway v. Artic, 547 F. Supp. at 1014. Yet if substantial economic harm to the original author were an explicit element in identifying component works, perhaps cases like Midway v. Artic would be inore carefully decided, even on a inotion for preliminary injunction. 
have clearer guidance in briefing and arguing their position. As a result, courts will inore easily come to carefully reasoned decisions.

With the harm analysis conducted properly, the courts can pursue both of copyright law's opposing goals. If the work is a component work and does not cause harm to the original author, then allowing the component work's distribution does not harm the original author; his incentives are secure. Moreover, since the public will now have access to the component work, which will enhance performance of the original work, the public interest will be advanced as well. Thus, component works delicately balance the two coinpeting ends of copyright law, and manage to achieve both.

\section{CONCLUSION}

The concept of component works lias yet to be recognized expressly. Nonetheless, as this Comment has argued, existing copyright law provides the tools required to protect component works. The narrow definition of derivative work, the market test for infrimgement, and the ideaexpression distinction all serve to protect component works. In the other direction, the liberal test for derivative works, the substantial similarity test for infrimgement, and the look-and-feel doctrine disrupt the fundamental balance underlying copyright law when applied to prohibit coinponent works. The public interest in the proinotion of technology and access to knowledge is precariously balanced against the authors' interests in financial rewards. Yet when the authors' incentives are guaranteed, copyright law can afford to maximize the public's interest in knowledge. In other words, when one end of the scale is unchangeable, society can pursue the other end without disrupting the balance. Coinponent works allow that pursuit and maintain the balance.

Finally, although existing law can protect coinponent works, unwitting protection of component works in erratic decisions is unsatisfactory. Thus, this Comment proposes judicial recognition of component works, by judicially created exception, or witl explicit protection under existing doctrimes. Sucli judicial creation is liardly novel in the copyright arena. Indeed, "fair use" is a judicially created doctrime. Judicial creation is needed to bridge the void between 1970s copyright law and 1990s technology. Every statute relies upon judicial gloss for fine tuning, if not explanation. The course of progress has raised many new copyright questions, and the Supreme Court has provided a means for responding: "When technological change has rendered its literal terms ainbiguous, the Copyriglit Act inust be construed in light of [its] basic purpose."204

204. Twentieth Century Music Corp. v. Aiken, 422 U.S. 151, 156 (1975); see also Fortnightly Corp. v. United Artists Television, Inc., 392 U.S. 390, 396 (1968) ("We must read the statutory language ... in the light of drastic technological change."). 
The component works doctrine addresses the frontiers of our burgeoning copyright law by hearkening to its two fundamental goals. 
